\title{
Value and small firm premiums in the South African market
}

\author{
S. Hammar* \\ School of Economics, University of Cape Town, Private Bag, Rondebosch, 7701 \\ *To whom all correspondence should be addressed \\ stuart,hammar@gmail.com
}

\begin{abstract}
Numerous studies have identified both value and size effects existing in international markets. Fewer studies have been conducted that document the same effects in the South African market. In this study, portfolios were constructed based on four valuation multiples, as well as market capitalisation from 1999 2012. In this 14-year period it was found that value stocks predominantly outperformed growth stocks when defined by $\mathrm{P} / \mathrm{E}$ or $\mathrm{P} / \mathrm{CF}$. Growth stocks outperformed value stocks when the portfolios were based on P/B and DY. Also, significant evidence of a small firm premium was identified on the JSE, regardless of the valuation multiple. Furthermore, small-cap value stocks generated the highest mean returns over the period. The study identifies the prevalence of these premiums on the JSE, but the comprehensive explanations for these anomalies remain inconclusive.
\end{abstract}

\section{Introduction}

Historically, academics and investors have focused their research on understanding and evaluating growth and value firms, generally with large market capitalisations (Dimson, Nagel \& Quigley, 2003). As a result, the variety of investor valuations and opinions - often guided by academic research for exploiting market anomalies unique to these companies - is extensive.

At a simplistic level, individuals and institutions tend to invest in value and growth stocks (Chan \& Lakonishok, 2004). Typically, value stocks are understood as being "cheap" or facing financial difficulty - defined as having low price multiples (Lakonishok, Shleifer \& Vishny, 1994; Fama \& French, 1998). Investors tend to buy these stocks in anticipation of a business turnaround and to capitalise on them being undervalued. The converse is true for growth stocks, which are stereotypically expensive - exhibiting high price multiples. The reason for buying growth stocks is to profit from their high growth potential. For investment security, risk aversion and lower transaction costs, investors prefer purchasing the stock of large companies displaying either of the aforementioned traits. Naturally, this all points to the widely documented analysis of whether value stocks outperform growth stocks, and to the existence of a value effect (Lakonishok et al., 1994).

Large, mature companies are known as large-cap companies. Conversely, smaller and less mature companies are domned small-caps. The "cap" refers to the market capitalisation of the business, which is defined as the product of the number of outstanding shares and the company's share price. However, less investor focus has been placed on the smaller (and often less mature) companies. This phenomenon may be attributed to the higher risk profile associated with small firms (Roll, 1981).
The resulting neglect leads to fewer reliable valuations, stock illiquidity, and limited stock information being available for such companies (Arbel \& Strebel, 1982; Damodaran, 2012: 335-7). This lack of information, illiquidity of stock and lack of investor interest may lead to anomalies in the market, which investors can exploit namely through the size effect, initially documented by Banz (1980).

From the many studies conducted internationally as well as those conducted domestically, in South African markets, a number of investment strategies have emerged that exploit investment in either value or small-cap stocks. For example, Basu (1977), Banz (1980), Roll (1980), Lakonishok et al. (1994), Fama and French (1998), and Bauman, Conover and Miller (1998) have confirmed these two anomalies internationally, while Graham and Uliana (2001), Van Rensburg and Robertson (2003), Strugnell, Gilbert and Kruger (2011), Auret and Cline (2011), and Hodnett, Hsieh and Van Rensburg (2012) have studied them domestically.

The theories that are tested in this study pertain to the widely researched value premium, as well as the small firm premium that may exist on the Johannesburg Stock Exchange (JSE).

The remainder of this article proceeds as follows: the next section reviews prior domestic and international research surrounding the value effect, size effect, and mean reversion. After which is a description of the raw data obtained and the research methodology that was applied, followed by the results that were obtained by conducting ttests on the average annual portfolio returns. These results suggest that not only do the size and value premiums exist on the JSE, but so does a growth premium. The final section concludes the article by drawing on the results derived, as well as suggesting a direction for future work. 


\section{Literature review}

To explore the existence of both a value and size premium on the JSE, it is important to understand and analyse previous empirical and theoretical studies pertaining to both international and domestic markets. Firstly, the value premium is examined, followed by the size premium and lastly, literature concerning mean reversion is discussed.

\section{The value premium}

Extraordinary investors, namely Warren Buffett and Philip Fisher, have been successful in buying and selling both value and growth stocks, respectively. However, the dispute rages on as to which type of stock yields the highest return while offering the lowest risk.

Value stocks are conventionally defined as stocks that exhibit low price to book (P/B) ratios; low price earnings (P/E) ratios; high dividend yields (DY) (Basu, 1977; Fama \& French, 1992; Damodaran, 2012: 259); low price to cash flow (P/CF) (Lakonishok et al., 1994); and historically low earnings per share (EPS) relative to the market. Value investors buy stocks that are cheaper than their underlying fundamentals indicate.

By contrast, growth stocks are defined as having multiples with the opposite characteristics to value stocks: high price to book, high price earnings, low dividend yield, high price to cash flow, and high past growth rates in EPS relative to the market (Bauman et al., 1998). Growth investors buy shares that have high growth potential for a low price.

By 1998, a number of studies of the US stock market had shown that value stocks outperformed growth stocks, but the reasons for this return differential is varied. Fama and French (1992) offered the explanation that value stocks were more risky than growth stocks, and as a result would compensate for this risk through higher returns. Opposing this, Lakonishok et al. (1994) and Chan and Lakonishok (2004) found that common risk measures did not justify the evidence of a value premium; hence value stocks were not more risky than growth stocks. Instead, they found that value stocks yielded higher returns due to investors overestimating expected returns on growth stocks relative to value stocks - simply put: this is an example of suboptimal investor behaviour.

Bauman and Miller (1997, cited in Bauman et al., 1998) concurred with the previous finding. They noticed that the growth rate in EPS displayed qualities of mean reversion. Thus, the historically high growth rates in EPS associated with growth stocks would decline and the previously low growth rates in EPS exhibited by value stocks would increase. They concluded that analysts overestimated the growth in EPS of growth stocks relative to value stocks. Therefore, achieved returns on growth shares were lower than expected, because of analysts' high expectations.
Bauman et al. (1998) conducted research on the existence of a value premium existing outside the US, in international markets. The results of their study suggested that value stocks were as dominant in international markets as they were in the US market. Fama and French (1998) arrived at similar conclusions about international markets, and also found that these traits were exhibited in developing markets. The value premium was also found to occur on the London Stock Exchange between 1955 and 2001, as identified by Dimson et al. (2003). Blount (2010) validates this further in an article stating that growth stocks do not grow, He wrote about a study of 10000 global stocks over 35 years that proved that value stocks outperformed both growth stocks and the market, while growth stocks underperformed the market.

Graham and Uliana (2001) conducted a study on the value effect on the JSE from 1987 - 1996. They found that growth outperformed value shares pre-1992, and that value outperformed growth post-1992 suggesting that the turnaround might have been the result of political and economic factors. Van Rensburg and Robertson (2003), Strugnell et al. (2011), and Hodnett et al. (2012) all noted that a value effect existed on the JSE. However, Auret and Cline (2011) found the opposite, i.e., that neither a value nor growth effect existed on the JSE.

\section{The small firm premium}

Apart from the difference in investment styles between growth and value investors, there is also the question of whether to invest in large- or small-cap stock. Investors also dispute whether small-cap stocks, on average, outperform large-cap stocks, thus exhibiting a small firm size premium, and whether this is associated with small firm risks (Roll, 1981; Reinganum, 1982).

Large-cap stocks are generally associated with large and reputable businesses (Eun, Huang \& Lai, 2008) with large market capitalisations. The opposite is true for small-caps, which are stereotypically more risky investments, since they do not always grow to become mid- to large-caps. Previously, they may have even been large- or mid-caps that are now in distress (Chan \& Chen, 1991).

The risk is due to small businesses being small for a reason: either they have just started up and are growing; or they may be a marginal firm - defined as having lost value due to weak performance, high leverage, poor cash flows, and exhibit inefficiencies in production (Chan \& Chen, 1991). Brink (2010) stated that small-cap stocks are less frequently traded (or less liquid) than large-cap stocks. As a result, fewer investors research small-cap firms, resulting in less information in the market about them. He goes on to say that the omus is on the investor to select high-quality small-cap stocks in order to benefit from the small firm premium.

Banz (1980) examined the relationship between market cap and return in the US market, and found that small-cap stocks earned higher risk-adjusted returns than large-cap stocks. 
Fama and French (1992) and, later confirmed by Barber and Lyon (1997), found that small firms outperformed large firms in the periods they tested. Banz also noted that there was a less significant difference in returns between mid- to large-cap firms. Banz suspected that the size effect might be as a result of additional factors, rather than size alone. One factor was that a lack of information about small firms generated a demand for higher returns.

Arbel and Strebel (1982) found that the amount of research done on a firm was strongly related to a return premium, rather than being solely associated with size. The less researched (or more neglected) the firm, the higher were the returns. The lack of information surrounding the stock created uncertainty for the investor, which resulted in a return premium being demanded. It was found that the neglected firms were generally small-caps rather than largecaps.

Roll (1981) explained that the small firm effect arose due to risk being incorrectly calculated for small firms. This underestimation of risk resulted in over-estimated riskadjusted returns for small firms, hence the subsequent superior returns. Reinganum (1982) tested Roll's theory and found that small firm risk was understated, but the underestimation did not completely account for the small size effect. Horowitz, Loughran and Savin (2000) conducted research on the US market between 1980 and 1996, the results of which refuted the existence of a size premium. Of the three methodologies used, none suggested the existence of a small firm premium. Their conclusion was that the size effect was strictly academic and was implausible in practice.

Differences in risk between large and small firms have been found, but firm size itself is not the sole cause. Riskier firms tended to be marginal firms and marginal firms have higher expected rates of return than firms that are not. A large proportion of small-cap firms comprise marginal firms, which may aceount somewhat for the small firm premium (Chan \& Chen, 1991).

Bauman et al. (1998) conducted a study on growth versus value and large-cap versus small-cap in international markets. Their conclusions were that value stocks outperformed growth stocks except for the portfolio containing the smallest firms. Dhatt, Kim and Mukherji (1999) conducted a similar study on the performance of small-cap value stocks in the US market. Their results showed that small-cap value stocks outperformed growth stocks and that most of this premium arose outside of January. This is contradictory to Keim (1982) who found that almost $50 \%$ of the size effect was due to small firms experiencing abnormal returns in January relative to large firms.

In the South African context, Auret and Cline (2011) found that neither the January effect nor the small firm effect existed on the JSE in the periods that they studied. However, research conducted by Van Rensburg and Robertson (2003), Strugnell et al. (2011), and Hodnett et al. (2012) contradict
Auret and Cline's results and found a size effect to reside on the JSE,

\section{Mean reversion: Winner versus loser portfolios}

As with trying to capitalise on value and size anomalies, investors and academics have tried to generate excess returns by utilising the mean reverting characteristic of markets, as well as trying to explain why stocks do revert to normal prices.

Prior to Fama and French (1988) and Poterba and Summers (1988), studies had looked at autocorrelation over short time periods. However, Fama and French (1988) and Poterba and Summers (1988) opted to look at autocorrelations over longer time periods. They found that in periods longer than a year, there was significant negative autocorrelation, illustrating the mean reverting qualities of stock prices in both the US and international markets. Later research (Jagadeesh, 1991) identified mean reversion in the equally weighted index on both the New York and London Stock Exchanges, thus confirming the findings of Fama and French and Poterba and Summers. However, the mean reverting properties were found to occur mostly in January.

Opposing this, Kim, Nelson and Startz (1991) found mean reversion to be strictly associated with pre-war stock prices and no evidence of mean reversion was found post-war. Their research was re-examined by McQueen (1992), who found that pre-war mean reversion was overstated due to the types of statistical tests conducted. He found that, by using a different analysis, mean reversion did not exist in the periods tested by $\mathrm{Kim}$ et al. (1991). Similar results were found in an international study of 18 indexes, where most of the indexes did not show evidence of mean reversion (Cochran \& DeFina, 1994). The indexes that exhibited mean reversion were explained by country-specific factors.

More recent research (Balvers, Wu \& Gilliland, 2000) found that there was much controversy surrounding mean reversion, and explained that numerous studies had argued against Fama and French and Poterba and Summers' findings. Much of the controversy surrounded the availability of high-quality long-term time series, which were needed to detect mean reversion. However, in Balvers, Wu and Gilliland's research spanning 27 years of share data, they found evidence of mean reversion in stock prices, and that it took approximately 3,5 years for a stock to return halfway to its mean price.

Some explanations of mean reversion are closely related to investor overreaction to stock information (De Bondt \& Thaler, 1985; Muller, 1999). Therefore, if bad (good) news about a stock arises, investors overreact, and the share price will fall (rise) more than it should. Inevitably, the market corrects itself over time, and the share price rises (falls) to its supposed normal price (Page \& Way, 1992). This leads to a strategy of buying "loser" stocks - stocks that have fallen the most over a period - and selling "winner" stocks - 
stocks that have increased the most over the past period - to take advantage of mean reversion (Damodaran, 2012; 285).

In 1985, De Bondt and Thaler found that mean reversion existed for US stocks that had faced long-term gains or losses; therefore, previous losers performed better than previous winners. They noted that the loser portfolios outperformed the winner portfolios by approximately $25 \%$ $30 \%$, between three and five years after the portfolios were formed. In addition, the loser portfolios earned excess returns in January for up to five years. In a follow-up paper (De Bondt \& Thaler, 1987) evidence was found that corroborated their earlier paper, despite compensating for firm size and risk differences.

In terms of a short-term holding strategy - between three and twelve months - Jagadeesh and Titman (1993) suggest buying winners and selling losers. They found that the length of the holding period of a loser or winner portfolio could affect returns; this was due to short-term price momentum (six to twelve months) benefiting winner portfolios, and long-term price reversals (three to five years) aiding loser portfolios. Their results illustrated that the winners outperformed the losers in the first year, but after one year, the winners' outperformance began to dissipate. However, it was noted that it could take in excess of 36 months for the loser portfolios to outperform the winners.

Researchers such as Page and Way (1992), Muller (1999), Cubbin et al. (2006), and Hsieh and Hodnett (2011) have explored the less developed South African market for mean reversion and investor overreaction. Page and Way (1992) analysed the JSE over the 1974 - 1989 period for overreactions and subsequent reversion. The results of their analysis indicated that using return information from previous periods might lead to predictable future returns. They also found that, on average, loser portfolios outperformed winners by approximately $20 \%$ within three years of portfolio construction - indicating the long-term nature of mean reversion, which is consistent with the aforementioned international studies. However, the January effect, mentioned previously, was not as pronounced on the JSE as it was in the US market.

An analysis of the 1985 - 1998 period, found that loser portfolios on the ISE outperformed winner portfolios by $5 \%$ and the market by $20 \%$ (Muller, 1999). Evidence of shortterm price momentum was also noted for the winners, while long-term mean reversion was present in the loser portfolios, which is consistent with Jagadeesh and Titman's (1993) findings. Therefore, Muller suggested that holding $20-40$ equally weighted winner shares over a short period, or holding 20 - 30 losers for longer than a year would have generated excess returns over the market in the period examined. Muller only used the top 200 shares on the JSE in his study so the actual largest winners and losers were omitted. This survivorship bias may have affected his results.

Cubbin et al. (2006) constructed portfolios of the top and bottom 35 shares - defined by their $\mathrm{P} / \mathrm{E}$ ratios - following
De Bondt and Thaler's (1985) methodology. Included in the portfolios were all of the shares that had been delisted, as well as those listed, between 1983 and 2005 to compensate for the survivorship bias. Their results ratify Page and Way (1992) and Muller's (1999) results of loser portfolios outperforming winners in the long-term on the JSE. Their results show that the winner portfolios experienced upward momentum for roughly eight months; thereafter the loser portfolios began to outperform the winners. This differs from De Bondt and Thaler's (1985) results that showed the loser portfolios outperforming the winners immediately.

Hsieh and Hodnett (2011) found evidence of mean reversion and loser portfolio outperformance that validates that of Page and Way (1992), Muller (1999), and Cubbin et al. (2006). Furthermore, Hsieh and Hodnett considered that when there was a financial downturn, a contrarian investment strategy might be a secure investment strategy.

The aim of this article is to empirically test whether these premiums do in fact exist on the JSE in the $1999-2012$ period. This differs from previous work, as the time period being investigated is very recent. In addition, portfolios were constructed on the basis of four valuation multiples, as well as by market capitalisation - differing from prior research conducted on the JSE where only one price multiple was chosen and tested. The former portfolios were used to identify a value premium; the latter determined whether a size premium existed. The portfolios based on the four multiples were then sub-divided by market capitalisation to investigate whether the value and size premiums occurred independently of each other. In summation, this paper attempts to provide a broader set of results than have previously been obtained. It also serves to be one of the most current explorations into the presence of the value and size effects on the JSE.

\section{Data and methodology}

The closing share prices, $\mathrm{P} / \mathrm{B}, \mathrm{P} / \mathrm{E}, \mathrm{P} / \mathrm{CF}, \mathrm{DY}$, and market capitalisations for the listed shares on the JSE main board were all obtained from Bloomberg (using the relevant Microsoft Excel formula) for each month-end for the period $1992-2012$. However, only the data for the 14-year period spanning 31 December 1998 - 31 December 2012 were utilised. The stock history relates to the 165 members comprising the JSE Africa All Share Index (JALSH) as of January 2013. The JALSH was selected because it contains the companies that make up the top $99 \%$ of the total market capitalisation of the JSE.

The data received from $\mathrm{Bloomberg}$ were not modified for look-ahead bias; therefore, the multiples were all current and not lagged. Due to the data pertaining to the 14-year history of the current JALSH members, the initial years of data were not always complete, or had very few members. This is as a result of the current members not yet being included in the index, or even being listed at the time. 
Using this share information, portfolios were constructed following the methodology of Bauman et al. (1998). However, each portfolio was created in January and held for 12 months, as opposed to using differing portfolio construction dates due to varying firm financial year-ends.

A Microsoft Excel model was used to assemble the portfolios, calculate the return information, and perform the necessary statistical tests.

To investigate whether a value effect exists on the JSE, value-growth multiples were used to form quartiles. Each quartile was equivalent to one portfolio, which aided in identifying the type of stock in the portfolios. The first quartile of the $\mathrm{P} / \mathrm{B}$ portfolios contained the stocks with the lowest $\mathrm{P} / \mathrm{B}$ ratios, generally associated with value stocks. The second and third quartiles housed the stocks with the second lowest and second highest $\mathrm{P} / \mathrm{B}$ ratios, respectively. The last quartile, with the highest $\mathrm{P} / \mathrm{B}$ ratios, contained the growth stocks. The structure of the $\mathrm{P} / \mathrm{E}$ and $\mathrm{P} / \mathrm{CF}$ portfolios was identical to that of the $\mathrm{P} / \mathrm{B}$ portfolios. In terms of $\mathrm{DY}$, the first quartile included stocks with a high ratio, thus value shares; the fourth quartile held stocks with a low DY, hence classified as growth stocks. The portfolios were reformed in every year of the 14-year period.

To test the evidence of a small firm premium, portfolios based on market capitalisation were constructed following the same principles as above. Shares with the smallest market capitalisations fell into the first quartile; conversely, the fourth quartile contained the shares with the largest market capitalisations.

At the end of each year, the average return and standard deviation were calculated for each quartile. Using the returns, the spread between the first and fourth quartiles was computed. The significance of the spread was calculated using the two-tailed Student's t-test for equal or unequal variances. A two-tailed t-test was chosen so as to determine whether or not there was a significant difference in the spread, regardless of the direction of the difference. Only ttest p-values that were less than $10 \%$ were considered as being significant. The equality of variances was determined by using the F-test for equal variances. If the F-test was significant at the $10 \%$ level, the variances were deemed unequal and the appropriate t-test was conducted. It is important to note that the calculation used for all standard deviations assumes that all share returns are perfectly correlated, i.e., that there is no diversification - this is a conservative approach.

At the end of the 14-year period, the arithmetic and geometric mean returns, as well as the standard deviations, for the portfolios were computed. In addition to the portfolio returns, the mean return for the JALSH was included each year, as well as its arithmetic and geometric mean return for the entire period. This aided in assessing the performance of the portfolios over the entire period. In addition to these data, the total number of observations was reported.
Value-growth multiples were further sub-divided into groups based on market capitalisation - resulting in 16 subgroups per multiple. The purpose of this was to identify whether a value premium was stronger in small- or large-cap firms, as well as which multiple provided the strongest indication of this effect, if it existed. Due to a lack of complete stock information in the early years of the study (mentioned earlier), any null returns were assumed to be a $0 \%$ return.

The geometric annual mean returns were computed over the 14-year period for each sub-group. The column- and rowbased average returns were computed, as well as the spread between the value and growth quartiles. The data were then observed to uncover any underlying trends over the complete period.

This methodology expands on the work done by Graham and Uliana (2001), Van Rensburg and Robertson (2003), Auret and Cline (2011), and Strugnell et al. (2011). Each of these sets of authors only used one valuation multiple either $\mathrm{P} / \mathrm{E}, \mathrm{P} / \mathrm{B}$ or book-to-market - in their research. The use of four commonly used ratios applied to 14 years of market data allows a broader set of comparative results to be formulated.

\section{Portfolio performance and discussion}

The results are presented in this section in three parts. The first and second parts are presented in the form of a onefactor model to establish whether the value and size premiums occurred, respectively. The one-factor model calculated the annual returns for each of the individual multiples (P/B, P/E, P/CF, DY, and market capitalisation) in isolation. The third part utilises a two-factor model, where the valuation multiples were sub-divided by market capitalisation to identify if any interaction between the value and size premiums existed.

\section{The value premium}

Based on the background research conducted, the price to book, price to earnings, price to cash flow, and dividend yield appeared to be the most common valuation criteria for firms. The performance of the quartile portfolios was examined each year to gauge the consistency of the return differential between value and growth stocks.

Table 1 displays the total number of stock returns observed each year, as well as the portfolio returns that are classified by $\mathrm{P} / \mathrm{B}$. The value portfolios outperformed growth in only four of the years; growth outperformed value in the other ten years. In two of the four years, value outperformed growth with statistical significance, whereas growth showed statistically significant outperformance in four of its ten years. Overall, the geometric mean return for the value portfolios $(23,6 \%)$ fell short of the growth portfolios' $(28,2 \%)$ by 450 bps. The growth portfolio also showed lower volatility than the value portfolio. The value portfolio was, in fact, the most volatile of the portfolios, followed by 
Quartile 3. The growth portfolio also exhibited higher riskadjusted returns than the value portfolio - illustrated by the risk/return ratio (the arithmetic mean over standard deviation) in Table 1 . The risk/return ratio measures the return generated by a portfolio per one unit of risk. Quartile 2 actually exhibited the lowest return but displayed a riskadjusted return higher than Quartile 1, due to its low volatility. The return data for the four quartiles from Table 1 are graphed in Figure 1. Quartiles 1 and 4 are shown in Figure 1a, and Quartiles 2 and 3 are graphed in Figuare 1b (simply for comparison). From these figures it is evident that over the period, each quartile outperformed the index, although not in every year. The large drop in returns in 2008 is attributable to the 2008 credit crisis. Using this as a focal point in Figure 1a, it is noticeable that prior to the crisis, value stocks (Quartile 1) mostly outperformed growth. But post-2008, growth stocks (Quartile 4) have been outperforming value, which is an interesting turnaround.

Table 1: Portfolio returns and standard deviations by year for value and growth stocks based on P/B, $1999-2012$.

\begin{tabular}{|c|c|c|c|c|c|c|c|}
\hline \multirow[b]{3}{*}{ Time Period } & \multirow[b]{3}{*}{$\begin{array}{c}\text { Total } \\
\text { Observations } \\
\end{array}$} & \multicolumn{4}{|c|}{ Value-Growth Quartile } & \multirow[b]{3}{*}{$\begin{array}{l}\text { Spread between } \\
\text { Quartiles } 1 \text { and } 4\end{array}$} & \multirow[b]{3}{*}{$\begin{array}{c}\text { JALSH } \\
\text { Mean Return }\end{array}$} \\
\hline & & \multicolumn{2}{|l|}{ Value } & \multicolumn{2}{|r|}{ Growth } & & \\
\hline & & 1 & 2 & 3 & 4 & & \\
\hline $1 / 99-12 / 99$ & 195 & & & & & & \\
\hline Return & & $85,1 \%$ & $80,7 \%$ & $87,4 \%$ & $86,6 \%$ & $-1,5 \%$ & $54,5 \%$ \\
\hline Standard Deviation & & $54,2 \%$ & $51,4 \%$ & $39,2 \%$ & $54,5 \%$ & & \\
\hline $1 / 00-12 / 00$ & 718 & & & & & & \\
\hline Return & & $1,2 \%$ & $1,7 \%$ & $-0,1 \%$ & $6,7 \%$ & $-5,4 \%$ & $-1,4 \%$ \\
\hline Standard Deviation & & $49,5 \%$ & $32,1 \%$ & $43,1 \%$ & $40,7 \%$ & & \\
\hline $1 / 01-12 / 01$ & 1074 & & & & & & \\
\hline Return & & $59,0 \%$ & $33,1 \%$ & $35,8 \%$ & $20,3 \%$ & $38,8 \%$ & $16,9 \%$ \\
\hline Standard Deviation & & $61,9 \%$ & $25,2 \%$ & $42,4 \%$ & $37,4 \%$ & & \\
\hline $1 / 02-12 / 02$ & 1165 & & & & & & \\
\hline Return & & $20,5 \%$ & $19,9 \%$ & $23,6 \%$ & $14,5 \%$ & $6,0 \%$ & $-10,2 \%$ \\
\hline Standard Deviation & & $47,6 \%$ & $31,9 \%$ & $28,0 \%$ & $34,6 \%$ & & \\
\hline $1 / 03-12 / 03$ & 1239 & & & & & & \\
\hline Return & & $46,3 \%$ & $24,3 \%$ & $31,8 \%$ & $32,5 \%$ & $13,9 \%$ & $18,1 \%$ \\
\hline Standard Deviation & & $66,0 \%$ & $39,5 \%$ & $29,2 \%$ & $35,8 \%$ & & \\
\hline $1 / 04-12 / 04$ & 1314 & & & & & & \\
\hline Return & & $40,7 \%$ & $32,1 \%$ & $60,0 \%$ & $43,6 \%$ & $-3,0 \%$ & $16,7 \%$ \\
\hline Standard Deviation & & $38,2 \%$ & $25,8 \%$ & $25,3 \%$ & $28,8 \%$ & & \\
\hline $1 / 05-12 / 05$ & 1371 & & & & & & \\
\hline Return & & $61,1 \%$ & $42,4 \%$ & $45,0 \%$ & $42,4 \%$ & $18,7 \%$ & $41,4 \%$ \\
\hline Standard Deviation & & $35,3 \%$ & $27,9 \%$ & $25,7 \%$ & $28,8 \%$ & & \\
\hline $1 / 06-12 / 06$ & 1402 & 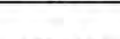 & & & & & \\
\hline Return & & $38,1 \%$ & $42,4 \%$ & $40,5 \%$ & $45,8 \%$ & $-7,6 \%$ & $26,2 \%$ \\
\hline Standard Deviation & & $29,9 \%$ & $27,0 \%$ & $28,0 \%$ & $29,8 \%$ & & \\
\hline $1 / 07-12 / 07$ & 1510 & & & & & & \\
\hline Return & & $6,5 \%$ & $29,0 \%$ & $32,7 \%$ & $31,4 \%$ & $-24,9 \%$ & $13,8 \%$ \\
\hline Standard Deviation & & $24,0 \%$ & $28,8 \%$ & $28,5 \%$ & $27,8 \%$ & & \\
\hline $1 / 08=12 / 08$ & 1595 & & & & & & \\
\hline Return & & $-30,4 \%$ & $-28,8 \%$ & $-26,7 \%$ & $-21,4 \%$ & $-9,0 \%$ & $-21,3 \%$ \\
\hline Standard Deviation & & $40,6 \%$ & $39,3 \%$ & $44,3 \%$ & $50,6 \%$ & & \\
\hline $1 / 09-12 / 09$ & 1635 & & & & & & \\
\hline Return & & $15,6 \%$ & $32,7 \%$ & $30,4 \%$ & $37,4 \%$ & $-21,8 \%$ & $34,5 \%$ \\
\hline Standard Deviation & & $42,0 \%$ & $36,1 \%$ & $33,2 \%$ & $29,2 \%$ & & \\
\hline $1 / 10-12 / 10$ & 1675 & & & & & & \\
\hline Return & & $25,0 \%$ & $25,7 \%$ & $22,0 \%$ & $34,3 \%$ & $-9,3 \%$ & $20,4 \%$ \\
\hline Standard Deviation & & $27,3 \%$ & $26,4 \%$ & $22,4 \%$ & $21,6 \%$ & & \\
\hline $1 / 11-12 / 11$ & 1710 & & & & & & \\
\hline Return & & $1,2 \%$ & $-4,5 \%$ & $2,3 \%$ & $11,1 \%$ & $-9,9 \%$ & $1,9 \%$ \\
\hline Standard Deviation & & $20,1 \%$ & $20,0 \%$ & $19,0 \%$ & $21,0 \%$ & & \\
\hline $1 / 12-12 / 12$ & 1751 & & & & & & \\
\hline Return & & $9,2 \%$ & $26,6 \%$ & $33,9 \%$ & $40,6 \%$ & $-31,4 \%$ & $16,2 \%$ \\
\hline Standard Deviation & & $24,1 \%$ & $22,9 \%$ & $21,7 \%$ & $20,2 \%$ & & \\
\hline Portfolio Performance, $1 / 99-12 / 12$ & & & & & & & \\
\hline Geometric Mean Return & & $23,6 \%$ & $23,0 \%$ & $27,1 \%$ & $28,2 \%$ & $-4,5 \%$ & $14,6 \%$ \\
\hline Arithmetic Mean Return & & $27,1 \%$ & $25,5 \%$ & $29,9 \%$ & $30,4 \%$ & $-3,3 \%$ & $16,3 \%$ \\
\hline Standard Deviation of Returns & & $30,1 \%$ & $25,2 \%$ & $27,1 \%$ & $24,6 \%$ & & $20,0 \%$ \\
\hline Risk/Return Ratio & & 0,90 & 1,01 & 1,10 & 1,24 & & 0,82 \\
\hline
\end{tabular}

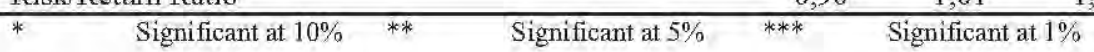




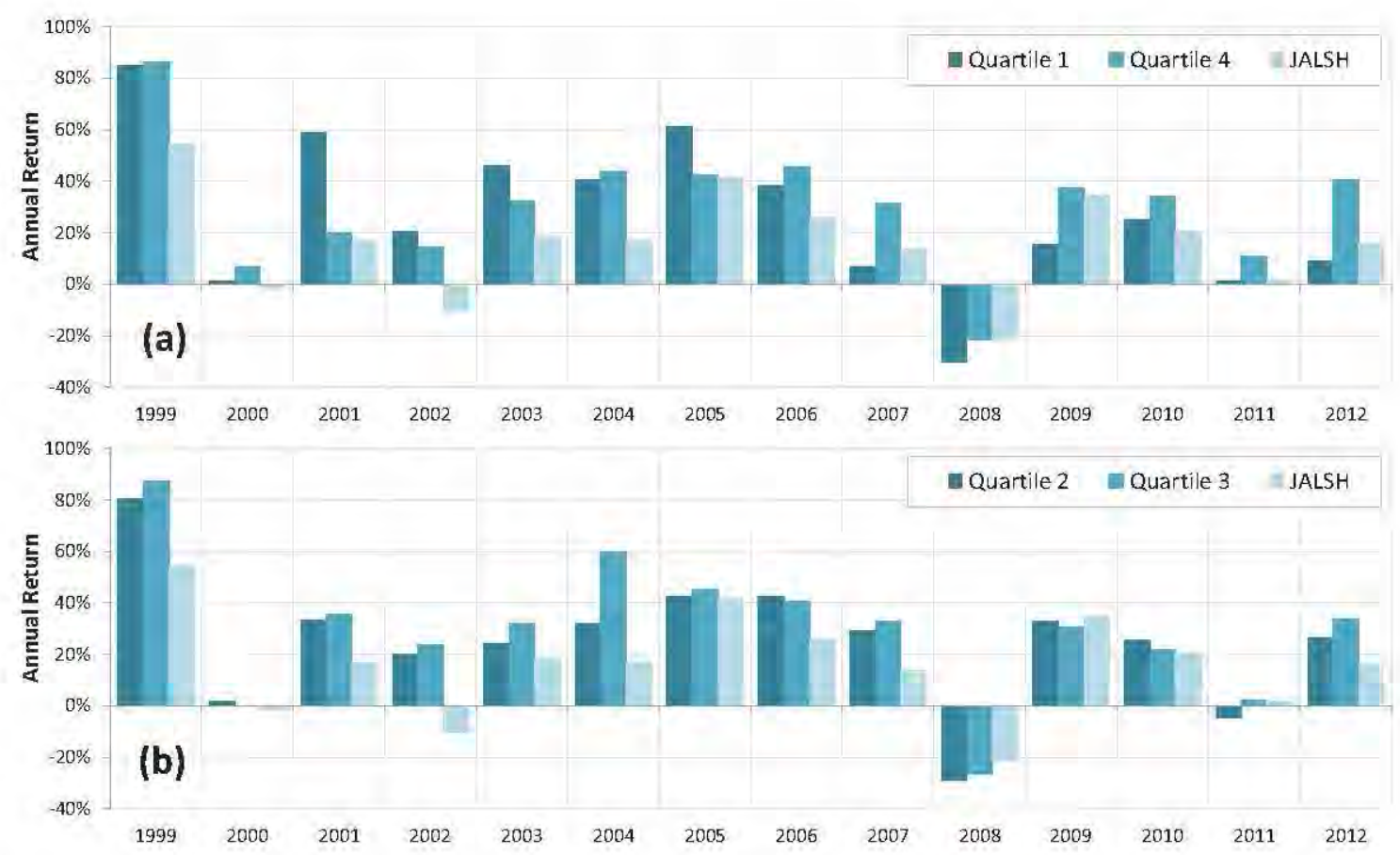

Figure 1: Portfolio and JALSH returns by year for value and growth stocks based on P/B, 1999-2012 for (a) quartiles 1 and 4 and (b) quartiles 2 and 3

The quartile portfolio returns of stocks based on $\mathrm{P} / \mathrm{E}$ are illustrated in Table 2, and it shows a different result to Table 1. In this instance, both the value and growth portfolios outperformed one another seven times each. For five of the seven years, the outperformance of the value portfolios was statistically significant. As opposed to this, none of the growth outperformances were significant. At the end of the 14-year period, the geometric mean return of the value portfolios was $33,6 \%$ (the highest of all the quartiles), 920 bps higher than the growth portfolios' return $(24,4 \%)$. As well as having the highest return, the value portfolios exhibited the highest variability; Quartiles 2 and 3 had the lowest standard deviations. Both Quartiles 2 and 3 displayed the highest risk-adjusted returns, with the value and growth portfolios having the second lowest and lowest, respectively. As with Figure 1, Figure 2 shows the results from Table 2 in graphical form. Figure $2 \mathrm{a}$, pertaining to the value (Quartile 1) and growth (Quartile 4) stocks, shows evidence of a value premium in the years prior to the credit crisis. Unlike the trend in Figure 1a, the value premium continues post-crisis, although it is somewhat diminished. Quartiles 2 and 3, seen in Figure $2 b$, show noticeably smaller and less erratic returns (between $-15 \%$ and $55 \%$ ) than Quartiles 1 and 2 (between $-35 \%$ and $122 \%$ ). 
Table 2: Portfolio returns and standard deviations by year for value and growth stocks based on P/E, 1999-2012

\begin{tabular}{|c|c|c|c|c|c|c|c|}
\hline \multirow{3}{*}{ Time Period } & \multirow[b]{3}{*}{$\begin{array}{c}\text { Total } \\
\text { Observations }\end{array}$} & \multicolumn{4}{|c|}{ Value-Growth Quartile } & & \multirow[b]{3}{*}{$\begin{array}{c}\text { JALSH } \\
\text { mean return }\end{array}$} \\
\hline & & \multicolumn{3}{|l|}{ Value } & \multirow{2}{*}{$\begin{array}{c}\text { Growth } \\
4 \\
\end{array}$} & & \\
\hline & & 1 & 2 & 3 & & $\begin{array}{l}\text { Spread between } \\
\text { Quartiles } 1 \text { and } 4\end{array}$ & \\
\hline $1 / 99-12 / 99$ & 104 & & & & & & \\
\hline Return & & $84,5 \%$ & $42,5 \%$ & $37,3 \%$ & $122,6 \%$ & $-38,1 \%$ & $54,5 \%$ \\
\hline Standard Deviation & & $63,8 \%$ & $40,1 \%$ & $39,0 \%$ & $45,6 \%$ & & \\
\hline $1 / 00-12 / 00$ & 418 & & & & & & \\
\hline Return & & $1,4 \%$ & $16,1 \%$ & $-14,8 \%$ & $3,6 \%$ & $-2,1 \%$ & $-1,4 \%$ \\
\hline Standard Deviation & & $37,0 \%$ & $36,8 \%$ & $40,4 \%$ & $38,1 \%$ & & \\
\hline $1 / 01-12 / 01$ & 949 & & & & & & \\
\hline Return & & $71,8 \%$ & $30,8 \%$ & $27,1 \%$ & $24,4 \%$ & $47,4 \%$ & $16,9 \%$ \\
\hline Standard Deviation & & $49,4 \%$ & $35,0 \%$ & $33,8 \%$ & $42,7 \%$ & & \\
\hline $1 / 02-12 / 02$ & 1091 & & & & & & \\
\hline Return & & $5,6 \%$ & $34,7 \%$ & $15,9 \%$ & $9,9 \%$ & $-4,2 \%$ & $-10,2 \%$ \\
\hline Standard Deviation & & $37,8 \%$ & $32,5 \%$ & $26,9 \%$ & $36,4 \%$ & & \\
\hline $1 / 03-12 / 03$ & 1140 & & & & & & \\
\hline Return & & $60,7 \%$ & $35,0 \%$ & $35,8 \%$ & $17,9 \%$ & $42,8 \%$ & $18,1 \%$ \\
\hline Standard Deviation & & $68,1 \%$ & $33,0 \%$ & $29,9 \%$ & $34,9 \%$ & & \\
\hline $1 / 04-12 / 04$ & 1179 & & & & & & \\
\hline Return & & $69,9 \%$ & $47,5 \%$ & $53,0 \%$ & $18,3 \%$ & $51,6 \%$ & $16,7 \%$ \\
\hline Standard Deviation & & $35,1 \%$ & $24,2 \%$ & $25,5 \%$ & $31,1 \%$ & & \\
\hline $1 / 05-12 / 05$ & 1251 & & & & & & \\
\hline Return & & $103,9 \%$ & $31,7 \%$ & $40,2 \%$ & $45,9 \%$ & $58,0 \%$ & $41,4 \%$ \\
\hline Standard Deviation & & $41,3 \%$ & $22,8 \%$ & $25,2 \%$ & $29,0 \%$ & & \\
\hline $1 / 06-12 / 06$ & 1252 & & & & & & \\
\hline Return & & $46,9 \%$ & $32,4 \%$ & $41,6 \%$ & $48,7 \%$ & $-1,8 \%$ & $26,2 \%$ \\
\hline Standard Deviation & & $33,2 \%$ & $27,2 \%$ & $27,0 \%$ & $28,5 \%$ & & \\
\hline $1 / 07-12 / 07$ & 1379 & & & & & & \\
\hline Return & & $27,9 \%$ & $10,4 \%$ & $26,6 \%$ & $37,5 \%$ & $-9,6 \%$ & $13,8 \%$ \\
\hline Standard Deviation & & $28,6 \%$ & $24,0 \%$ & $27,5 \%$ & $28,2 \%$ & & \\
\hline $1 / 08-12 / 08$ & 1508 & & & & & & \\
\hline Return & & $-35,1 \%$ & $-28,0 \%$ & $-19,3 \%$ & $-25,7 \%$ & $-9,4 \%$ & $-21,3 \%$ \\
\hline Standard Deviation & & $48,1 \%$ & $38,4 \%$ & $42,5 \%$ & $48,6 \%$ & & \\
\hline $1 / 09-12 / 09$ & 1516 & & & & & & \\
\hline Return & & $30,7 \%$ & $24,7 \%$ & $37,8 \%$ & $30,2 \%$ & $0,5 \%$ & $34,5 \%$ \\
\hline Standard Deviation & & $42,3 \%$ & $34,7 \%$ & $25,3 \%$ & $35,6 \%$ & & \\
\hline $1 / 10-12 / 10$ & 1559 & & & & & & \\
\hline Return & & $33,8 \%$ & $28,9 \%$ & $25,7 \%$ & $21,5 \%$ & $12,3 \%$ & $20,4 \%$ \\
\hline Standard Deviation & & $27,2 \%$ & $25,8 \%$ & $20,9 \%$ & $25,5 \%$ & & \\
\hline $1 / 11-12 / 11$ & 1663 & & & & & & \\
\hline Return & & $8,1 \%$ & $-1,4 \%$ & $0,9 \%$ & $3,0 \%$ & $5,1 \%$ & $1,9 \%$ \\
\hline Standard Deviation & & $21,0 \%$ & $17,6 \%$ & $18,6 \%$ & $21,6 \%$ & & \\
\hline $1 / 12-12 / 12$ & 1700 & & & & & & \\
\hline Return & & $32,7 \%$ & $25,7 \%$ & $22,5 \%$ & $33,7 \%$ & $-0,9 \%$ & $16,2 \%$ \\
\hline Standard Deviation & & $25,9 \%$ & $20,2 \%$ & $21,1 \%$ & $21,5 \%$ & & \\
\hline Portfolio Performance, $1 / 99=12 / 12$ & & & & & & & \\
\hline Geometric Mean Return & & $33,6 \%$ & $21,9 \%$ & $21,6 \%$ & $24,4 \%$ & $9,2 \%$ & $14,6 \%$ \\
\hline Arithmetic Mean Return & & $38,8 \%$ & $23,6 \%$ & $23,6 \%$ & $27,9 \%$ & $10,8 \%$ & $16,3 \%$ \\
\hline Standard Deviation of Returns & & $37,3 \%$ & $19,5 \%$ & $21,3 \%$ & $33,4 \%$ & & $20,0 \%$ \\
\hline Risk/Return Ratio & & 1,04 & 1,21 & 1,11 & 0,84 & & 0,82 \\
\hline
\end{tabular}




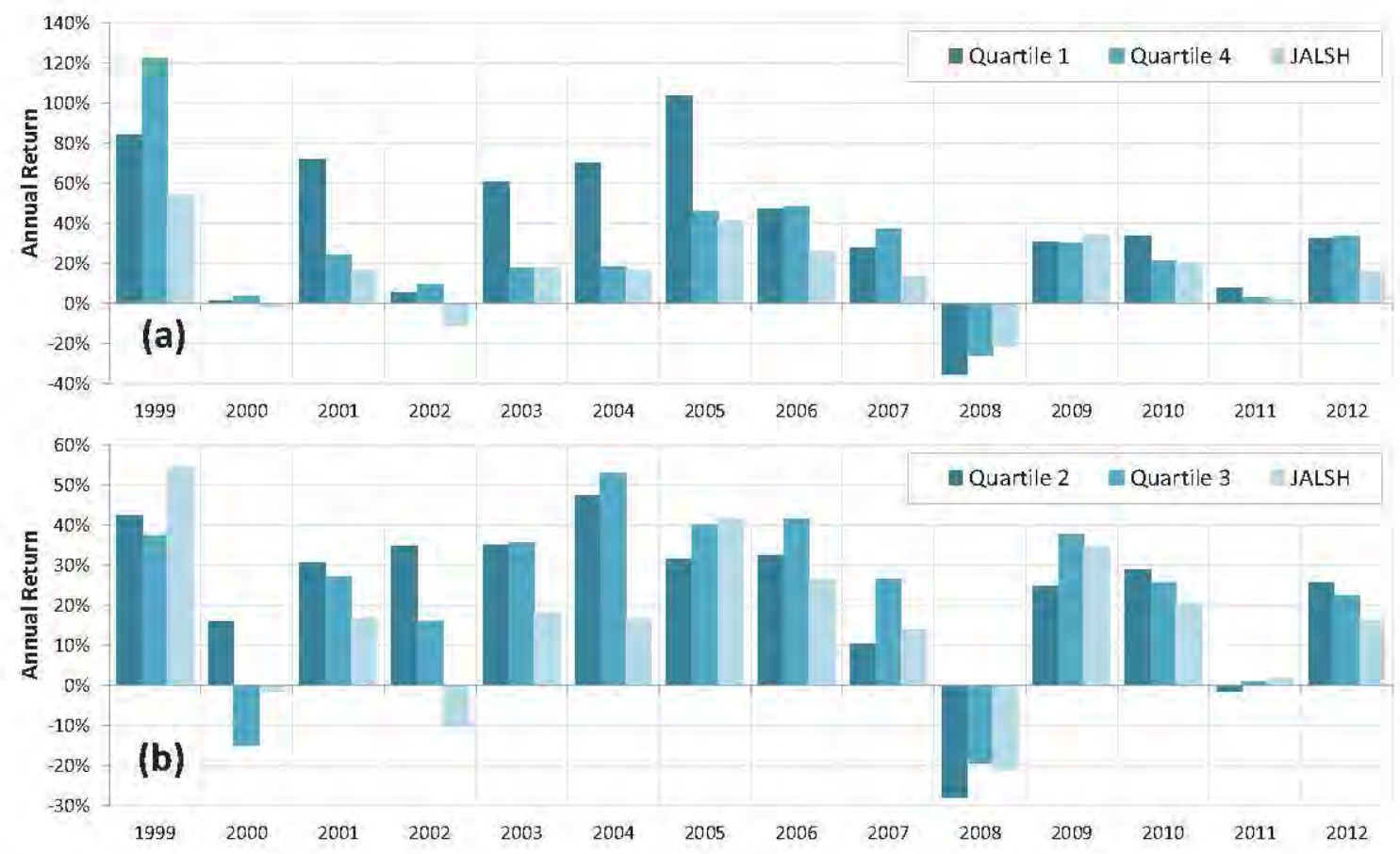

Figure 2: Portfolio and JALSH returns by year for value and growth stocks based on P/E, 1999-2012 for (a) quartiles 1 and 4 and (b) quartiles 2 and 3

When the portfolio quartiles are formed by $\mathrm{P} / \mathrm{CF}$, the results are comparable to those found by the $\mathrm{P} / \mathrm{E}$ portfolios. Table 3 shows that of the nine times that the value portfolios outperformed the growth portfolios, only three of those times were statistically significant. When growth outperformed value, only one of the results was significant, and the magnitude was not as large as the value outperformances. On the whole, the value portfolios exhibited a geometric mean return $(30,9 \%)$ that was 470 bps higher than the growth portfolios' $(26,1 \%)$. Again, the value portfolios illustrated the highest return, with Quartiles 2 and 3 having the lowest returns. Echoing the results found in Table 2, both Quartiles 2 and 3 had much lower volatilities than the value and growth portfolios. As a result, their riskadjusted returns were, in fact, much higher than the other two portfolios'. Following the same process as the previous tables, Table 3 has been graphed in Figure 3 with the returns of Quartiles 1 and 4 depicted in Figure 3a, and Quartiles 2 and 3 plotted in Figure $3 \mathrm{~b}$. Similar to Figure $2 \mathrm{a}$, the value effect persisted pre-2008. Post-crisis, any value stock outperformance has been matched by growth stock outperformance, rendering the post-crisis value effect to null. Over the whole period, each portfolio outperformed the JALSH. 
Table 3: Portfolio returns and standard deviations by year for value and growth stocks based on P/CF, $1999-2012$

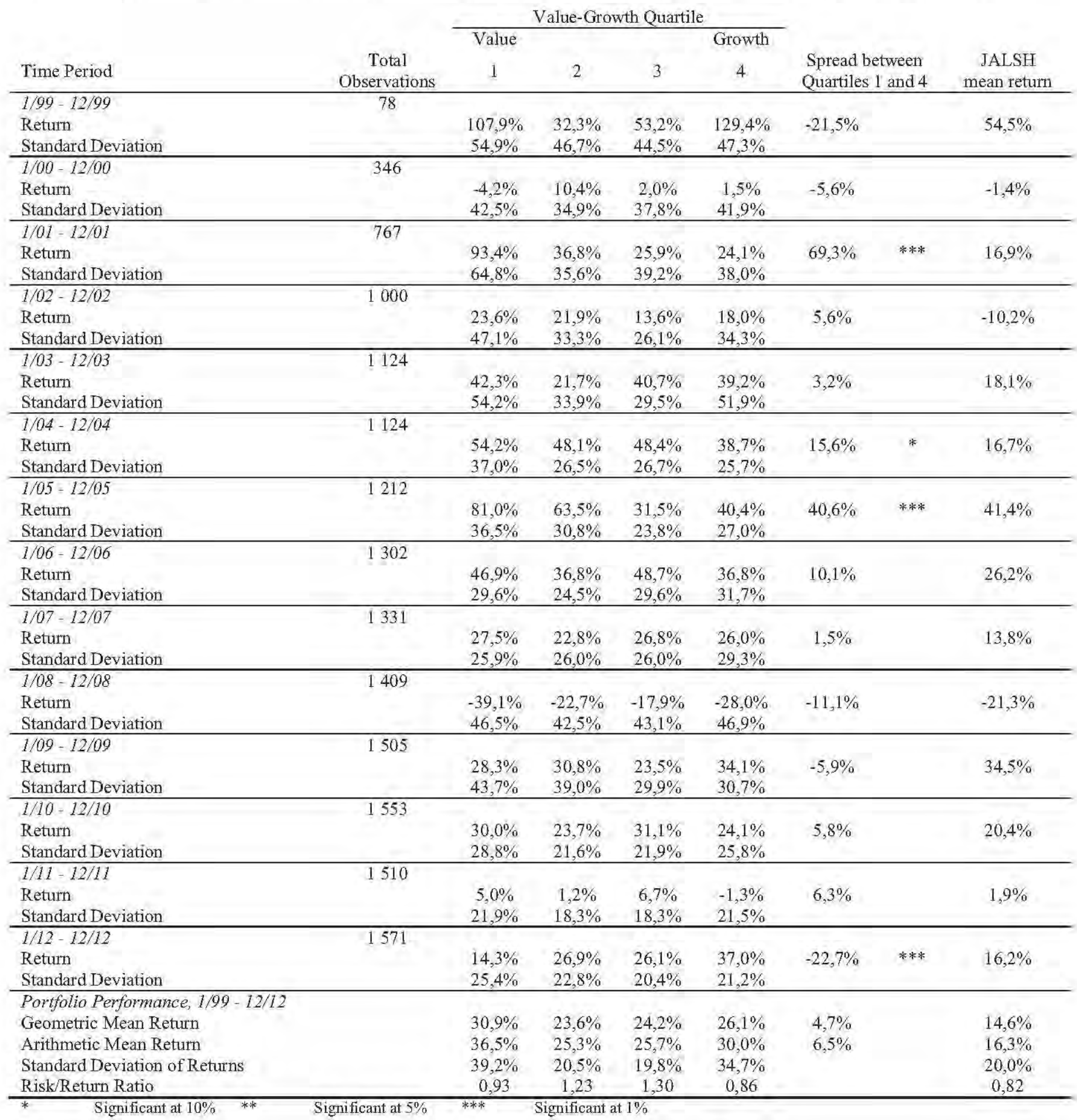




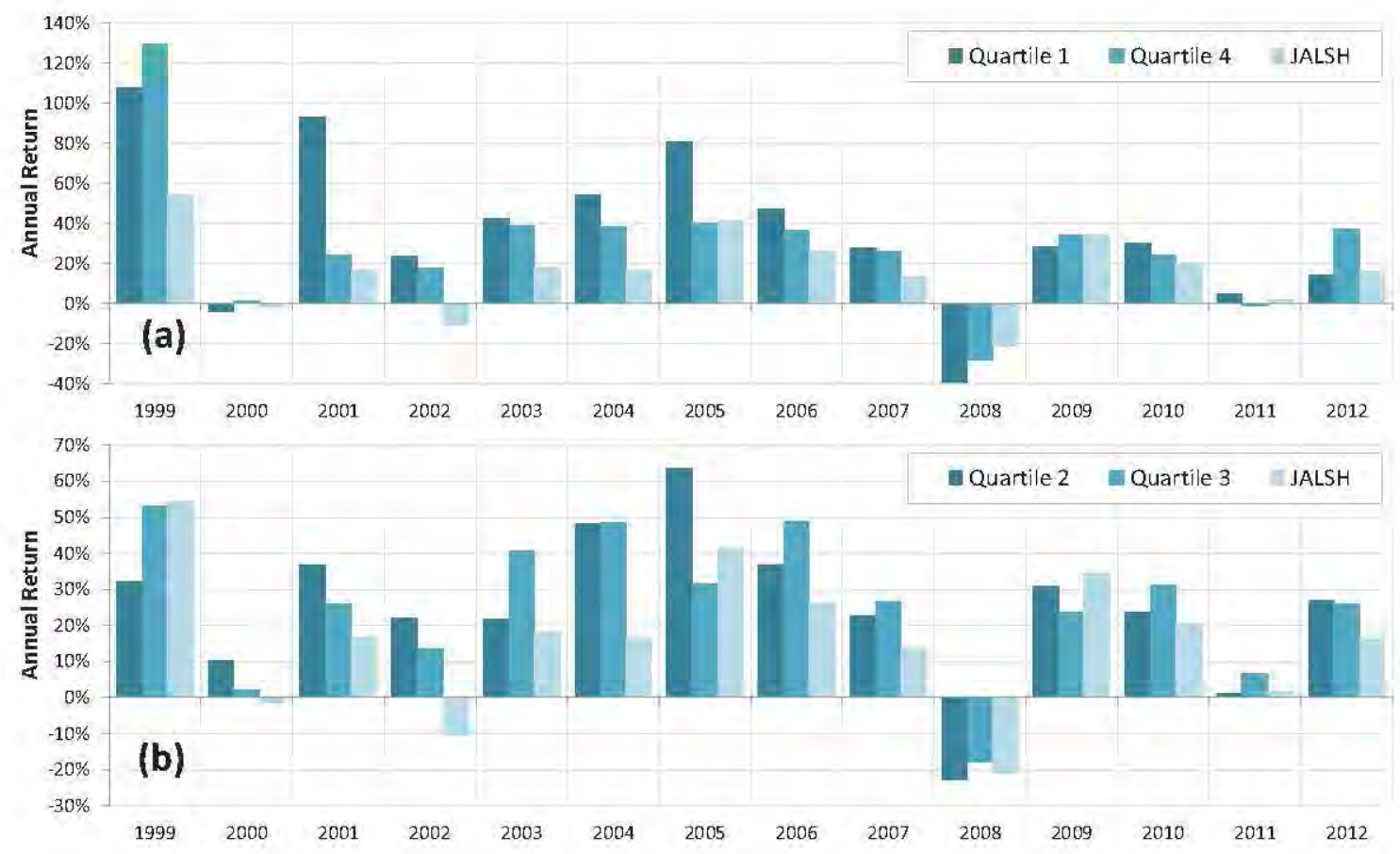

Figure 3: Portfolio and JALSH returns by year for value and growth stocks based on P/CF, 1999-2012 for (a) quartiles 1 and 4 and (b) quartiles 2 and 3

The data obtained from the portfolios formed by DY, see Table 4, showed that growth portfolios regularly outperformed value portfolios. These data have also been displayed graphically in Figure 4. Of the 14 years, the growth portfolios outperformed value in 12 of the years, often in excess of $10 \%$. Yet, of these 12 years, only four of the years displayed statistically significant results. By deduction, the value portfolio outperformed growth twice, and neither outperformance was significant. Over the whole period, the growth portfolios $(27,4 \%)$, followed by Quartiles $3(24,6 \%)$ and $2(22,4 \%)$ generated the highest geometric mean returns. The value portfolios lagged behind the growth portfolios by approximately $960 \mathrm{bps}$ over the period.
However, the value portfolios had the lowest volatility, and the growth portfolios had the highest variability in returns. Taking risk into account, the growth portfolios still maintained the highest risk-adjusted returns. The riskadjusted returns diminish as the portfolios become more value-based and less growth-based, as noted by Quartiles 3, 2 , and 1 . The performance of the value and growth stocks, shown in Figure $4 \mathrm{a}$, illustrates the consistent growth effect that persisted both pre- and post-crisis. As with the other value multiples, each portfolio outperformed the JALSH overall. 
Table 4: Portfolio Returns and standard deviations by year for value and growth stocks based on DY, 1999-2012

\begin{tabular}{|c|c|c|c|c|c|c|c|}
\hline \multirow[b]{3}{*}{ Time Period } & \multirow[b]{3}{*}{$\begin{array}{c}\text { Total } \\
\text { Observations }\end{array}$} & \multicolumn{4}{|c|}{ Value-Growth Quartile } & \multirow[b]{3}{*}{ Spread between } & \multirow[b]{3}{*}{$\begin{array}{l}\text { JALSH } \\
\text { mean return }\end{array}$} \\
\hline & & Growth & & & Value & & \\
\hline & & 1 & 2 & 3 & 4 & & \\
\hline $1 / 99-12 / 99$ & 973 & & & & & & \\
\hline Return & & $72,9 \%$ & $76,5 \%$ & $48,1 \%$ & $57,7 \%$ & $15,3 \%$ & $54,5 \%$ \\
\hline Standard Deviation & & $50,7 \%$ & $46,5 \%$ & $49,5 \%$ & $48,7 \%$ & & \\
\hline $1 / 00-12 / 00$ & 1022 & & & & & & \\
\hline Return & & $-10,4 \%$ & $7,6 \%$ & $-1,3 \%$ & $4,4 \%$ & $-14,8 \%$ & $-1,4 \%$ \\
\hline Standard Deviation & & $43,7 \%$ & $33,6 \%$ & $41,6 \%$ & $33,5 \%$ & & \\
\hline $1 / 01-12 / 01$ & 1023 & & & & & & \\
\hline Return & & $19,0 \%$ & $23,8 \%$ & $63,6 \%$ & $6,0 \%$ & $13,0 \%$ & $16,9 \%$ \\
\hline Standard Deviation & & $38,3 \%$ & $31,9 \%$ & $38,1 \%$ & $38,1 \%$ & & \\
\hline $1 / 02-12 / 02$ & 1068 & & & & & & \\
\hline Return & & $28,6 \%$ & $4,2 \%$ & $21,6 \%$ & $12,1 \%$ & $16,5 \%$ & $-10,2 \%$ \\
\hline Standard Deviation & & $35,7 \%$ & $31,8 \%$ & $32,7 \%$ & $28,4 \%$ & & \\
\hline $1 / 03-12 / 03$ & 1135 & & & & & & \\
\hline Return & & $35,3 \%$ & $35,1 \%$ & $26,5 \%$ & $23,7 \%$ & $11,6 \%$ & $18,1 \%$ \\
\hline Standard Deviation & & $32,1 \%$ & $29,5 \%$ & $35,5 \%$ & $31,0 \%$ & & \\
\hline $1 / 04-12 / 04$ & 1180 & & & & & & \\
\hline Return & & $48,5 \%$ & $45,1 \%$ & $53,3 \%$ & $34,7 \%$ & $13,8 \%$ & $16,7 \%$ \\
\hline Standard Deviation & & $31,2 \%$ & $25,5 \%$ & $24,3 \%$ & $25,3 \%$ & & \\
\hline $1 / 05-12 / 05$ & 1284 & & & & & & \\
\hline Return & & $59,5 \%$ & $48,3 \%$ & $42,3 \%$ & $42,5 \%$ & $17,0 \%$ & $41,4 \%$ \\
\hline Standard Deviation & & $32,3 \%$ & $25,8 \%$ & $27,0 \%$ & $25,9 \%$ & & \\
\hline $1 / 06-12 / 06$ & 1313 & & & & & & \\
\hline Return & & $53,5 \%$ & $36,0 \%$ & $33,3 \%$ & $33,5 \%$ & $20,0 \%$ & $26,2 \%$ \\
\hline Standard Deviation & & $28,1 \%$ & $24,5 \%$ & $25,8 \%$ & $30,6 \%$ & & \\
\hline $1 / 07-12 / 07$ & 1364 & & & & & & \\
\hline Return & & $43,6 \%$ & $24,5 \%$ & $4,8 \%$ & $12,8 \%$ & $30,8 \%$ & $13,8 \%$ \\
\hline Standard Deviation & & $27,8 \%$ & $24,7 \%$ & $25,2 \%$ & $22,8 \%$ & & \\
\hline $1 / 08-12 / 08$ & 1445 & & & & & & \\
\hline Return & & $-25,2 \%$ & $-28,4 \%$ & $-23,3 \%$ & $-25,6 \%$ & $0,3 \%$ & $-21,3 \%$ \\
\hline Standard Deviation & & $48,7 \%$ & $43,8 \%$ & $38,8 \%$ & $39,8 \%$ & & \\
\hline $1 / 09-12 / 09$ & 1478 & & & & & & \\
\hline Return & & $38,4 \%$ & $33,5 \%$ & $26,5 \%$ & $25,8 \%$ & $12,6 \%$ & $34,5 \%$ \\
\hline Standard Deviation & & $36,0 \%$ & $30,7 \%$ & $40,1 \%$ & $32,9 \%$ & & \\
\hline $1 / 10-12 / 10$ & 1512 & & & & & & \\
\hline Return & & $25,7 \%$ & $32,7 \%$ & $23,0 \%$ & $22,2 \%$ & $3,5 \%$ & $20,4 \%$ \\
\hline Standard Deviation & & $26,4 \%$ & $24,2 \%$ & $23,4 \%$ & $19,0 \%$ & & \\
\hline $1 / 11-12 / 11$ & 1678 & & & & & & \\
\hline Return & & $2,2 \%$ & $6,8 \%$ & $-1,0 \%$ & $4,2 \%$ & $-2,0 \%$ & $1,9 \%$ \\
\hline Standard Deviation & & $22,7 \%$ & $20,6 \%$ & $19,4 \%$ & $17,6 \%$ & & \\
\hline $1 / 12-12 / 12$ & 1734 & & & & & & \\
\hline Return & & $33,2 \%$ & $33,4 \%$ & $27,5 \%$ & $19,0 \%$ & $14,2 \%$ & $16,2 \%$ \\
\hline Standard Deviation & & $25,5 \%$ & $22,5 \%$ & $19,5 \%$ & $19,8 \%$ & & \\
\hline Portfolio Performance, $1 / 99-12 / 12$ & & & & & & & \\
\hline Geometric Mean Return & & $27,4 \%$ & $24,6 \%$ & $22,4 \%$ & $17,8 \%$ & $9,6 \%$ & $14,6 \%$ \\
\hline Arithmetic Mean Return & & $30,4 \%$ & $27,1 \%$ & $24,6 \%$ & $19,5 \%$ & $10,8 \%$ & $16,3 \%$ \\
\hline Standard Deviation of Returns & & $27,0 \%$ & $24,6 \%$ & $23,7 \%$ & $20,1 \%$ & & $20,0 \%$ \\
\hline Risk/Return Ratio & & 1,12 & 1,10 & 1,04 & 0,97 & & 0,82 \\
\hline
\end{tabular}

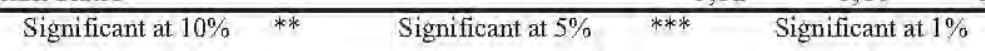




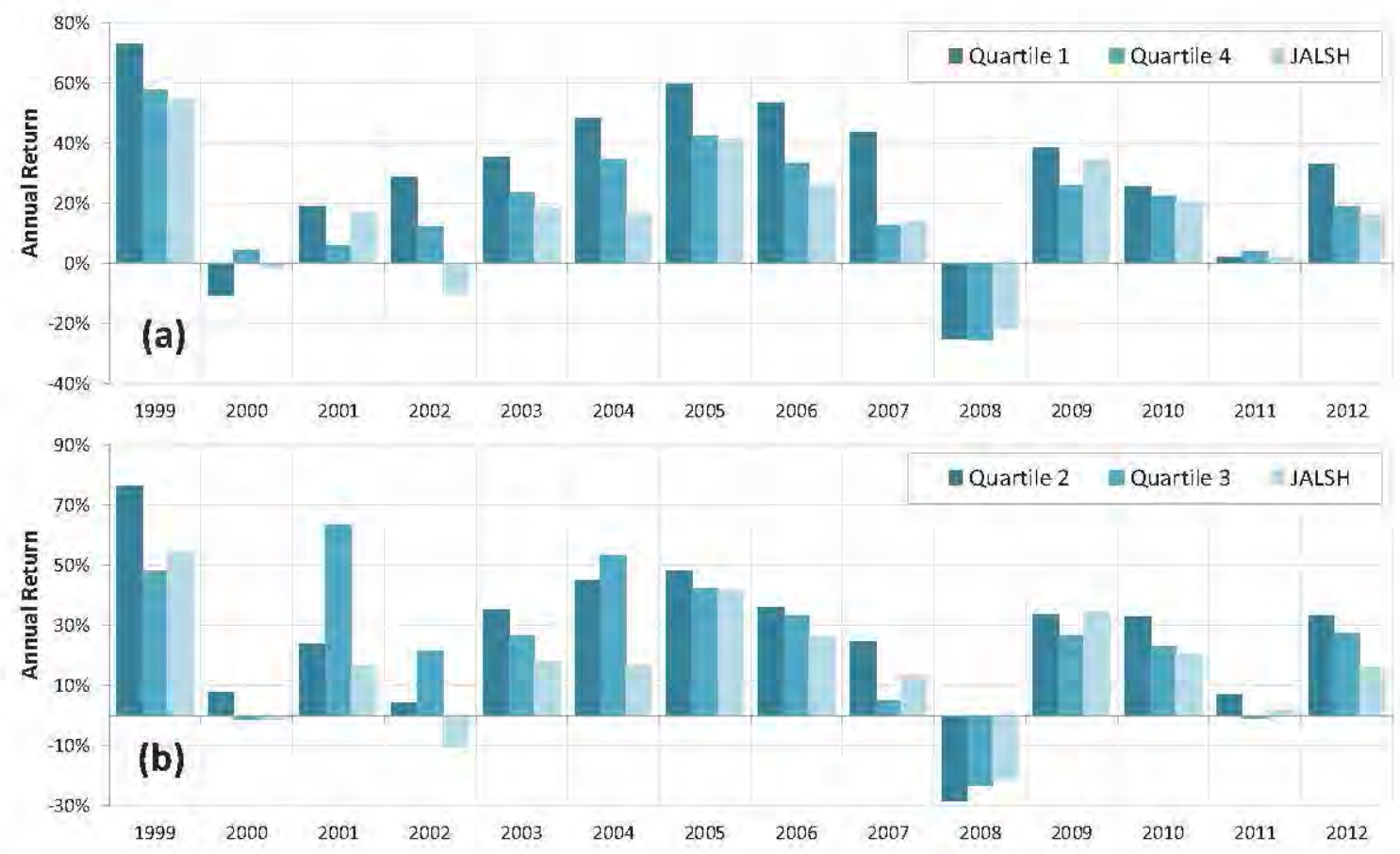

Figure 4: Portfolio and JALSH returns by year for value and growth stocks based on DY, 1999-2012 for (a) quartiles 1 and 4 and (b) quartiles 2 and 3

In summary, the overall results showed that each portfolio outperformed the index. In addition to the outperformance, each portfolio's risk-adjusted return was higher than the index's. However, the results do not show conclusive evidence of a value effect existing across all of the multiples, illustrating partial agreement with the international study conducted by Bauman et al. (1998).

More specifically, it can be noted that a strong value effect exists on the JSE when assessing portfolios based on the $\mathrm{P} / \mathrm{E}$ and $\mathrm{P} / \mathrm{CF}$ ratios, which is consistent with the South African findings by Van Rensburg and Robertson (2003), Strugnell et al. (2011), and Hodnett et al. (2012). These results reaffirm the initial research conducted in the United States by Basu (1977), and later verified by Fama and French (1992), that showed that low $\mathrm{P} / \mathrm{E}$ (value) stocks outperform high $\mathrm{P} / \mathrm{E}$ (growth) stocks. Furthermore, Lakonishok et al. (1994) also identified a value premium for low $\mathrm{P} / \mathrm{CF}$ and low $\mathrm{P} / \mathrm{E}$ businesses - echoed by the results identified above. Bauman et al. (1998) also observed the strong similarities between the $\mathrm{P} / \mathrm{E}$ and $\mathrm{P} / \mathrm{CF}$ portfolios. However, the results of the current study show that the value portfolios did not yield the highest risk-adjusted returns, instead Quartiles 2 and 3 had the highest risk/return ratios.

The P/B- and DY-based portfolios did not show evidence of a value effect; instead the growth portfolios were the top performers. This contradicts some of the findings outlined by Hodnett et al. (2012), namely that a value effect existed for portfolios based on DY and P/B. Bauman et al. (1998) also identified a value premium when portfolios were based on $\mathrm{P} / \mathrm{B}$ and $\mathrm{DY}$, which are also in opposition to the current study's results. Graham and Uliana (2001) found that value and growth stocks, defined by $\mathrm{P} / \mathrm{B}$, outperformed each other equally in their 10-year study on the JSE. Thus, showing neither a value nor growth effect enduring. The current paper opposes the findings of Dimson et al. (2003) that documented a value premium prevailing for DY-based portfolios.

An examination of value and growth portfolio performance before and after the 2008 credit crisis reveals two interesting results. Firstly, the value effect that prevailed pre-2008 for stocks based on $\mathrm{P} / \mathrm{B}$ turned into a growth effect after the crisis, seen in Figure 1a. Secondly, Figure 3a shows the opposite result occurring for stocks based on $\mathrm{P} / \mathrm{CF}$ - the value premium that existed pre-crisis has dissipated since 2008. Overall, the spreads between value and growth prior to 2008 have narrowed since the financial crisis.

Further observation showed that when the growth portfolios were the top performers, they also yielded the highest riskadjusted returns and the value portfolios yielded the lowest. It appears that the strongest value effect $(9,2 \%)$ persisted in the P/E-based portfolios; the DY-based portfolios experienced the strongest growth effect $(9,6 \%)$.

\section{The size premium}

To ascertain whether a size premium exists on the JSE, portfolio groups were constructed on the basis of market capitalisation, as opposed to value multiples. Table 5 shows the portfolio returns and standard deviations of the smalland large-cap portfolios. As a visual comparison, Figure 5 shows the return information for each of the size groups in Table 5. Of the 14 years examined, the portfolio with the smallest firms (Group A) outperformed the portfolio with the largest firms (Group D) for eight years; the opposite 
occurred for six years. The small-caps significantly outperformed the large-caps for six of the eight years; the large-caps had one significant result in their six years of outperformance. The outperformance of the small-cap portfolio translates into a geometric mean return $(30,4 \%)$ that is 1003 bps higher than the large-cap portfolio's $(20,2 \%)$. Group C (second largest firms) generated superior returns to the large-cap stocks as well.

The high return coupled with the small-cap stocks may be associated with a risk premium, suggested by the highest standard deviation being attributed to them. Bauman et al. (1998) found that small-caps exhibited the highest volatilities and that there was an inverse relationship between market cap and return volatility. Eun et al. (2008) found that mid-caps showed the lowest standard deviations overall, followed by large- and small-caps respectively. In this study, the second smallest (Group B) and second largest (Group C) firms both had the lowest standard deviations the two groups together are considered the mid-cap firms thereby validating Eun, Huang and Lai's (2008) results, as well as parts of Bauman, Conover and Miller's (1998). Overall, Group C exhibited superior risk-adjusted returns due to its fairly low volatility $(22,3 \%)$ coupled with a relatively high average return $(25,7 \%)$ - followed by Groups $\mathrm{A}, \mathrm{B}$, and D accordingly.

The graphed returns of the smallest- and largest-cap sizes (see Figure 5a) show that small-caps have continuously outperformed large-caps. The credit crisis seems to have affected the small-caps the most, as their returns fell to $33,7 \%$, more than $10 \%$ lower than Groups C and D. Yet, after the crisis small stocks continued to generate excess returns over both larger stocks and the market. But, the small-cap premium looks to have diminished slightly postcrisis. Figure $5 \mathrm{~b}$ shows that the spread between the second smallest and second largest stocks is approximately $5 \%$ over the period, with the second largest stocks consistently outperforming the smaller stocks.

Again it can be observed that each portfolio, defined by size, performed better than the JALSH, as well as generating higher risk-adjusted returns. The results show evidence of a small firm size premium existing on the JSE. Despite the returns not diminishing consistently when increasing the firm size - Group B has smaller geometric returns $(18,2 \%)$ than Group C (23,7\%) - Groups A and C both outperformed the largest-cap portfolio, Group D. On a risk-adjusted basis, Groups A, B, and C all outperformed Group D. Therefore, the regular and significant outperformance by small-cap firms is indicative of a small firm effect persisting on the JSE. However, it is still questionable how much of the premium is associated with risk.

These results corroborate the existence of a size premium existing on the JSE, as documented by Van Rensburg and Robertson (2003) and Strugnell et al. (2011). Although, it contradicts what Auret and Cline (2011) concluded about the JSE - that no size effect persists. The excess returns for small firms are also identified in international markets (Keim, 1983; Bauman et al., 1998; Eun et al., 2008). Although betas are not used in this study, Van Rensburg and Robertson (2003) and Strugnell et al. (2011) found that small-cap stocks had low betas. This indicated that there was surprisingly less risk associated with small-caps, despite their positive excess returns. Yet, in this study only standard deviations were utilised, which indicated higher risk associated with small-cap stocks as compared to large-caps, also discovered by Bauman et al. (1998) and Eun et al. (2008). Despite the higher risk, small-caps earned higher risk-adjusted returns than large-caps. The higher risk associated with small-caps, as well as the high risk-adjusted returns, appears to be in agreement with Bauman et als (1998) international study, as well as Banz's (1980) research. 
Table 5: Portfolio returns and standard deviations by year based on firm size, 1999-2012

\begin{tabular}{|c|c|c|c|c|c|c|c|}
\hline \multirow[b]{3}{*}{ Time Period } & \multirow[b]{3}{*}{$\begin{array}{c}\text { Total } \\
\text { Observations }\end{array}$} & \multicolumn{4}{|c|}{ Firm Size Group } & \multirow[b]{3}{*}{$\begin{array}{l}\text { Spread between } \\
\text { Groups A and D }\end{array}$} & \multirow[b]{3}{*}{$\begin{array}{c}\text { JALSH } \\
\text { mean return }\end{array}$} \\
\hline & & & \multicolumn{2}{|r|}{ Large } & & \\
\hline & & A & B & C & D & & \\
\hline $1 / 99-12 / 99$ & 867 & & & & & & \\
\hline Return & & $26,4 \%$ & $28,5 \%$ & $66,7 \%$ & $76,5 \%$ & $-50,1 \%$ & $54,5 \%$ \\
\hline Standard Deviation & & $52,4 \%$ & $56,1 \%$ & $49,1 \%$ & $45,8 \%$ & & \\
\hline $1 / 00-12 / 00$ & 1197 & & & & & & \\
\hline Return & & $-3,4 \%$ & $-0,2 \%$ & $-6,3 \%$ & $3,0 \%$ & $-6,4 \%$ & $-1,4 \%$ \\
\hline Standard Deviation & & $48,0 \%$ & $43,1 \%$ & $38,5 \%$ & $36,9 \%$ & & \\
\hline $1 / 01-12 / 01$ & 1311 & & & & & & \\
\hline Return & & $37,1 \%$ & $35,2 \%$ & $38,2 \%$ & $29,0 \%$ & $8,0 \%$ & $16,9 \%$ \\
\hline Standard Deviation & & $60,9 \%$ & $37,4 \%$ & $41,3 \%$ & $37,3 \%$ & & \\
\hline $1 / 02-12 / 02$ & 1351 & & & & & & \\
\hline Return & & $42,9 \%$ & $8,4 \%$ & $18,0 \%$ & $0,8 \%$ & $42,1 \%$ & $-10,2 \%$ \\
\hline Standard Deviation & & $44,7 \%$ & $31,7 \%$ & $33,3 \%$ & $37,0 \%$ & & \\
\hline $1 / 03-12 / 03$ & 1394 & & & & & & \\
\hline Return & & $50,3 \%$ & $26,3 \%$ & $31,4 \%$ & $14,0 \%$ & $36,3 \%$ & $18,1 \%$ \\
\hline Standard Deviation & & $73,2 \%$ & $32,9 \%$ & $28,2 \%$ & $34,1 \%$ & & \\
\hline $1 / 04-12 / 04$ & 1425 & & & & & & \\
\hline Return & & $62,5 \%$ & $37,1 \%$ & $44,3 \%$ & $30,9 \%$ & $31,6 \%$ & $16,7 \%$ \\
\hline Standard Deviation & & $39,1 \%$ & $27,6 \%$ & $23,7 \%$ & $25,5 \%$ & & \\
\hline $1 / 05-12 / 05$ & 1471 & & & & & & \\
\hline Return & & $97,1 \%$ & $38,2 \%$ & $34,5 \%$ & $47,6 \%$ & $49,5 \%$ & $41,4 \%$ \\
\hline Standard Deviation & & $40,3 \%$ & $29,7 \%$ & $24,3 \%$ & $28,3 \%$ & & \\
\hline $1 / 06-12 / 06$ & 1492 & & & & & & \\
\hline Return & & $43,5 \%$ & $34,4 \%$ & $44,0 \%$ & $44,0 \%$ & $-0,5 \%$ & $26,2 \%$ \\
\hline Standard Deviation & & $32,9 \%$ & $28,5 \%$ & $28,2 \%$ & $27,6 \%$ & & \\
\hline $1 / 07-12 / 07$ & 1571 & & & & & & \\
\hline Return & & $44,4 \%$ & $31,7 \%$ & $24,0 \%$ & $9,0 \%$ & $35,5 \%$ & $13,8 \%$ \\
\hline Standard Deviation & & $34,4 \%$ & $27,4 \%$ & $26,0 \%$ & $25,2 \%$ & & \\
\hline $1 / 08-12 / 08$ & 1655 & & & & & & \\
\hline Return & & $-33,7 \%$ & $-27,7 \%$ & $-22,1 \%$ & $-23,5 \%$ & $-10,2 \%$ & $-21,3 \%$ \\
\hline Standard Deviation & & $44,5 \%$ & $46,9 \%$ & $42,8 \%$ & $45,3 \%$ & & \\
\hline $1 / 09-12 / 09$ & 1700 & & & & & & \\
\hline Return & & $28,5 \%$ & $29,3 \%$ & $29,4 \%$ & $32,6 \%$ & $-4,0 \%$ & $34,5 \%$ \\
\hline Standard Deviation & & $42,2 \%$ & $32,3 \%$ & $32,5 \%$ & $36,0 \%$ & & \\
\hline $1 / 10-12 / 10$ & 1728 & & & & & & \\
\hline Return & & $40,3 \%$ & $22,0 \%$ & $27,8 \%$ & $16,0 \%$ & $24,3 \%$ & $20,4 \%$ \\
\hline Standard Deviation & & $28,8 \%$ & $23,7 \%$ & $22,2 \%$ & $24,3 \%$ & & \\
\hline $1 / 11-12 / 11$ & 1812 & & & & & & \\
\hline Return & & $10,7 \%$ & $-6,1 \%$ & $4,9 \%$ & $3,5 \%$ & $7,2 \%$ & $1,9 \%$ \\
\hline Standard Deviation & & $21,3 \%$ & $20,6 \%$ & $18,5 \%$ & $20,7 \%$ & & \\
\hline $1 / 12-12 / 12$ & 1890 & & & & & & \\
\hline Return & & $30,8 \%$ & $21,6 \%$ & $25,5 \%$ & $31,9 \%$ & $-1,0 \%$ & $16,2 \%$ \\
\hline Standard Deviation & & $26,3 \%$ & $21,1 \%$ & $22,5 \%$ & $20,1 \%$ & & \\
\hline Portfolio Performance, $1 / 99-12 / 12$ & & & & & & & \\
\hline Geometric Mean Return & & $30,4 \%$ & $18,2 \%$ & $23,7 \%$ & $20,2 \%$ & $10,3 \%$ & $14,6 \%$ \\
\hline Arithmetic Mean Return & & $34,1 \%$ & $19,9 \%$ & $25,7 \%$ & $22,5 \%$ & $11,6 \%$ & $16,3 \%$ \\
\hline Standard Deviation of Returns & & $30,4 \%$ & $19,4 \%$ & $22,3 \%$ & $24,7 \%$ & & $20,0 \%$ \\
\hline Risk/Return Ratio & & 1,12 & 1,03 & 1,16 & 0,91 & & 0,82 \\
\hline
\end{tabular}




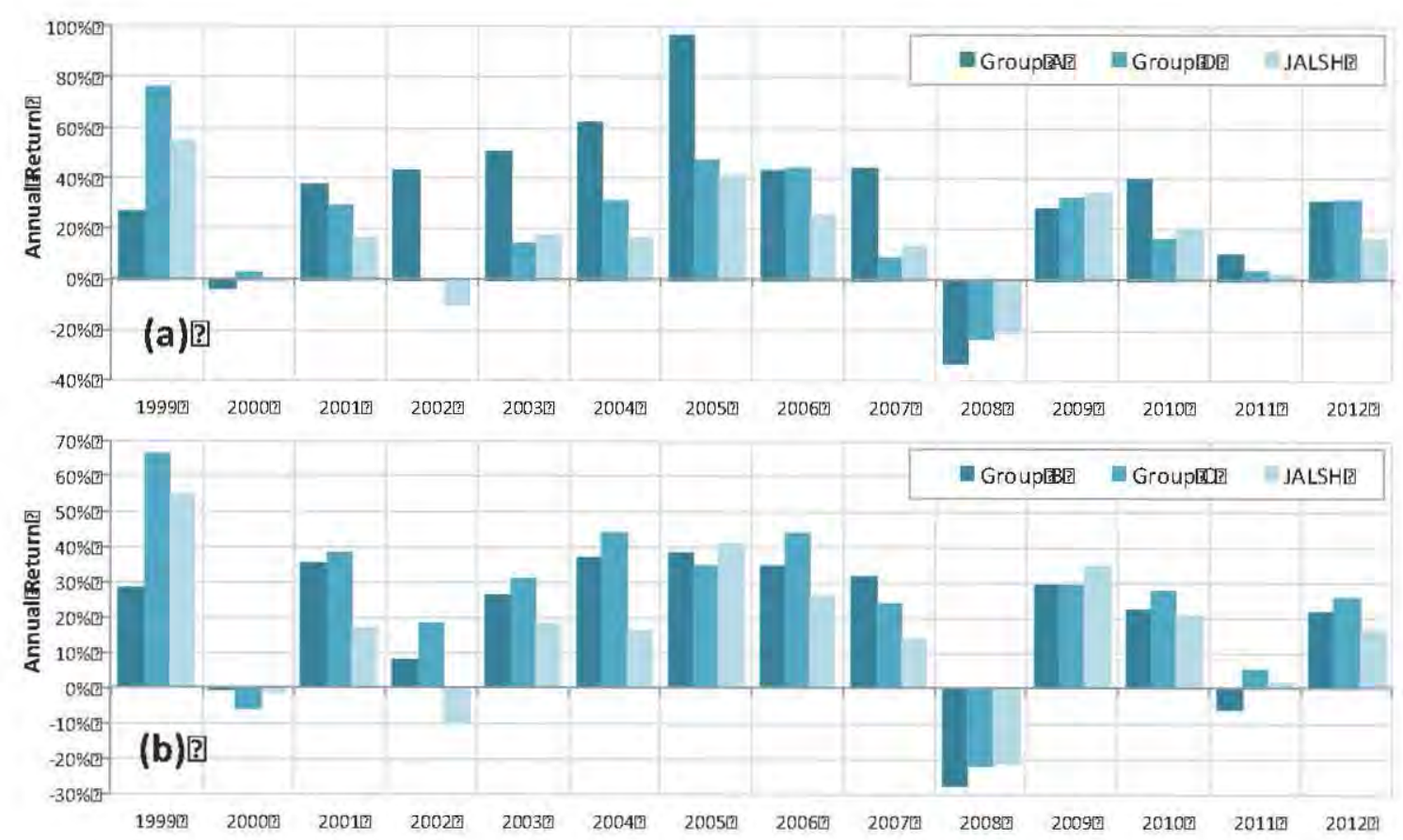

Figure 5: Portfolio and JALSH returns by year based on firm size, 1999-2012 for (a) groups A and D and (b) groups B and $C$

\section{Value and size premium interaction}

It is evident that a value, growth, and small firm premium existed on the JSE in the period examined. Although, evidence of the value and growth premiums depended on the valuation multiple used in the portfolios. The value quartiles were further sub-divided into four groups based on market cap - creating 16 sub-groups in total - to determine whether the value premium can be associated with firm size. For each multiple, the returns from the 16 sub-groups over the 14-year period were computed, and their corresponding geometric mean returns are presented in Table 6. It should be noted that Bauman et al. (1998) simply examined the average annual returns (arithmetic mean returns) of the 16 sub-groups. It was decided that a geometric mean return would be a more accurate and conservative representation of the results, as it assumes that the annual returns are not independent of each other. Also included are column- and row-based average returns, which demonstrate the value effect and size effect respectively. Each of the returns in Table 6 was graphed in Figure 6 and Figure 7. The former depicts the geometric returns in terms of the value effect, grouped by size quartile; the latter illustrates the returns in terms of the size premium, grouped by valuation quartile. 
Table 6: Geometric mean returns of value and growth stocks divided into groups by market capitalisation, 1999-2012

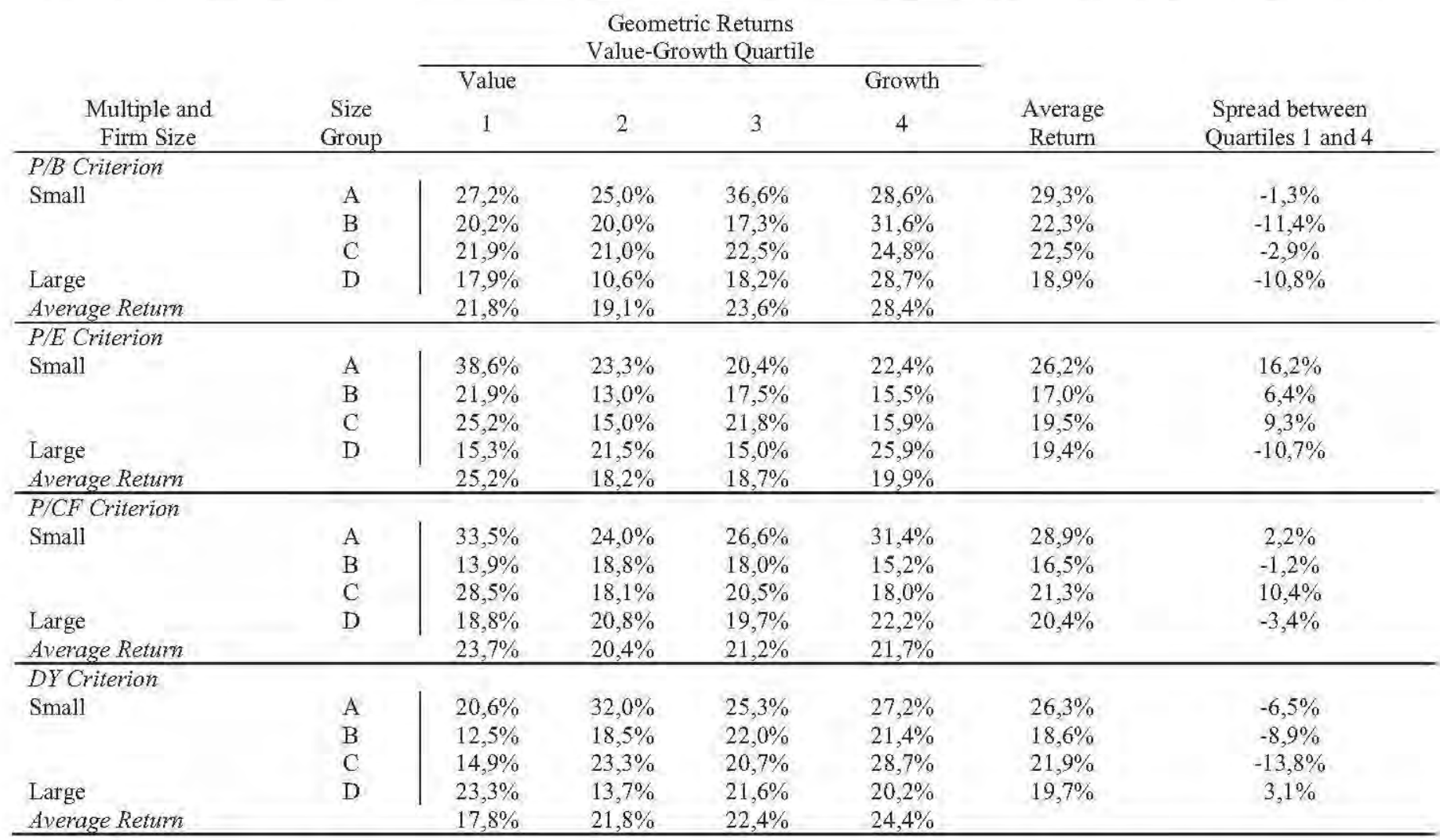

The columnar average returns show a value premium existing for the $\mathrm{P} / \mathrm{E}$ and $\mathrm{P} / \mathrm{CF}$ criteria: as the multiple increases, the returns consequently decrease - this is illustrated by the downward trending bars in Figure $6 \mathrm{~b}$ and Figure $6 \mathrm{c}$. The highest average value stock return was $25,2 \%$ for those in the $\mathrm{P} / \mathrm{E}$ criterion. However, a growth premium persists when the $\mathrm{P} / \mathrm{B}$ and $\mathrm{DY}$ criteria are examined: as the multiple shifts from value to growth, so the returns increase - visible by the upward trend in Figure $6 \mathrm{a}$ and Figure $6 \mathrm{~d}$. The highest average growth premium was $28,4 \%$, belonging to the $\mathrm{P} / \mathrm{B}$ criterion.

Examining the row-based average returns, it is evident that a size premium exists for all of the multiples across the JSE: as the firm size increases from small to large, the corresponding returns decrease by up to $10 \%$ - the downward trend in average mean returns clarifies this anomaly, apparent by the downward trending bars in all Figure 7 graphs, This corroborates the earlier findings of a size premium. The largest return was achieved by investing in the smallest-cap stocks grouped by $\mathrm{P} / \mathrm{B}$, earning $29,3 \%$ on average, followed by $\mathrm{P} / \mathrm{CF}(28,9 \%)$, DY $(26,3 \%)$, and $\mathrm{P} / \mathrm{E}$ $(26,2 \%)$. These column- and row-based observations are consistent with those found in the previous two sections of this study.
On the whole, the results from the two-factor model make it difficult to determine whether any additional trends persist. Therefore, it is worth examining each sub-table individually, beginning with $\mathrm{P} / \mathrm{B}$. A growth premium was identified, however, most of this premium arose due to the second smallest (Group B) and largest firm sizes (Group D) that show growth outperforming value by 1140 and 1080 bps respectively, depicted in Figure 6a. The smallest and second largest firms seem to have a weak growth effect, as both show excess returns of less than $3 \%$ for the growth stock.

The value premium identified by $\mathrm{P} / \mathrm{E}$ persists largely within the smallest size group (Group A), where value outperformed growth by 1620 bps (see Figure $6 \mathrm{~b}$ ). Groups B and $C$ follow suit with value outperforming growth by 640 and $930 \mathrm{bps}$ each. Interestingly, the largest firms exhibit a growth effect where growth outperformed value by 1070 bps.

Overall, the $\mathrm{P} / \mathrm{CF}$ sub-table (illustrated in Figure $6 \mathrm{c}$ ) displays a relatively small value premium of approximately $2 \%$, shown by the downward trending bars. Groups A, B, and $\mathrm{D}$ all display very little difference between value and growth performance. The second largest firms show the largest difference, with value outperforming growth by 1040 bps. 

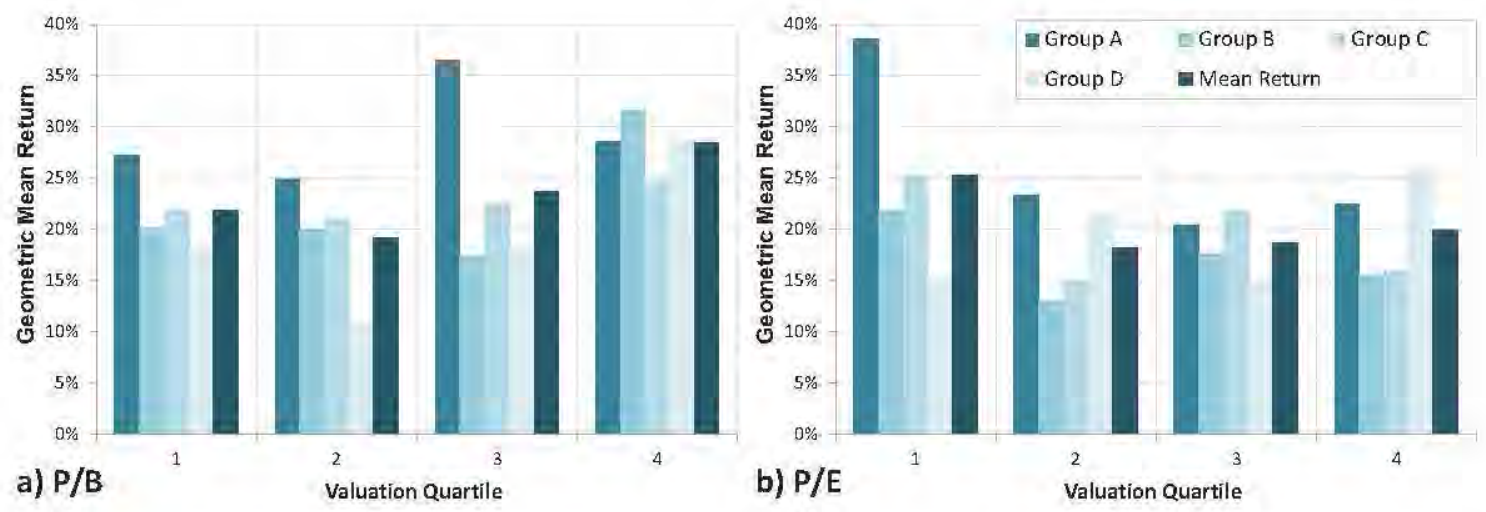

b) $P / E$

Valuation Quartile
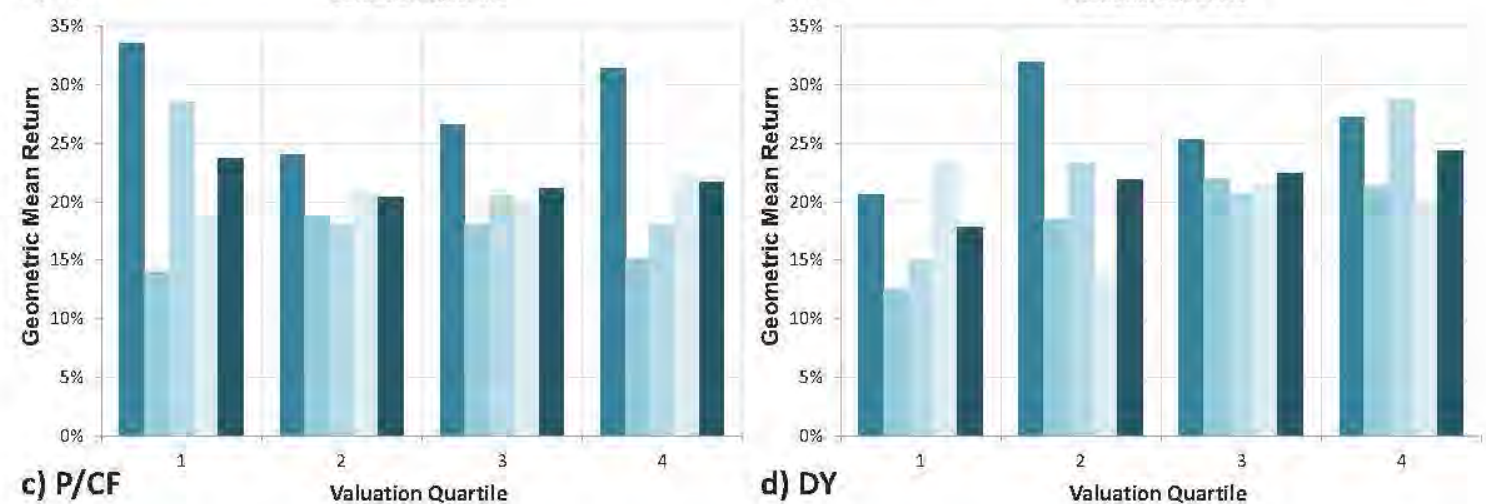

Figure 6: Portfolio returns based on valuation multiples to illustrate the value effect across all firm sizes, 1999-2012 for a) $\mathrm{P} / \mathrm{B}, \mathrm{b}) \mathrm{P} / \mathrm{E}, \mathrm{c}) \mathrm{P} / \mathrm{CF}$ and d) $\mathrm{DY}$

The final sub-table, graphed in Figure 6d, shows that Groups $\mathrm{A}, \mathrm{B}$, and $\mathrm{C}$ demonstrate moderate to strong growth outperformance of 650,890 , and 1380 bps respectively. The only group to exhibit a value premium $(3,1 \%)$ was Group D consisting of the largest firms.

At a macro level, large firms and the second smallest firms exhibited growth premiums averaging 540 and 380 bps over the period, respectively. A relatively small value premium averaging $260 \mathrm{bps}$ for the smallest firms and $80 \mathrm{bps}$ for the second largest firms - was earned over the period. However, of the four sub-tables, the largest value premium $(16,2 \%)$ was exhibited by the smallest firms when grouped by $\mathrm{P} / \mathrm{E}$. Contrary to this, the smallest value premium - or the largest growth premium - was earned by the second largest firms grouped by DY $(13,8 \%)$, as well as by the second smallest firms grouped by $\mathrm{P} / \mathrm{B}(11,4 \%)$.

The results, at a micro level, show returns that are in favour of investing in small-cap value firms. In both the $\mathrm{P} / \mathrm{E}$ and $\mathrm{P} / \mathrm{CF}$ tables, the sub-groups with the smallest firms within the first value quartile generated the highest geometric mean returns $(38,6 \%$ and $33,5 \%$, accordingly). Within the DY table, the highest geometric mean return (32\%) belongs to the smallest firms in the second value quartile. The $\mathrm{P} / \mathrm{B}$ table is the only table that indicates that one should rather invest in small-cap growth stock, with the highest geometric return $(36,6 \%)$ belonging to the third value quartile. Therefore, small-cap value stocks tend to outperform small-cap growth stocks, irrespective of the valuation multiple. 

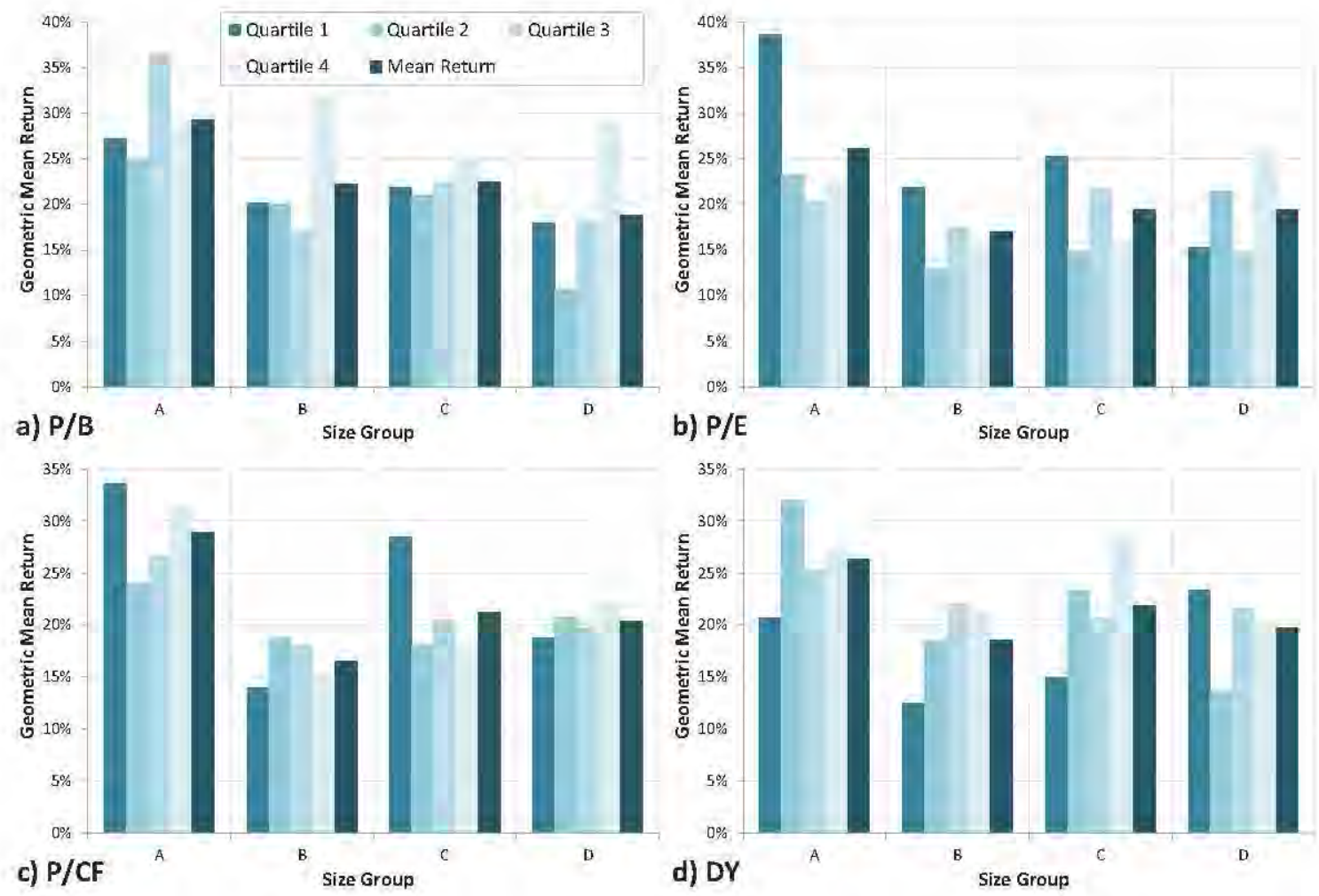

Figure 7: Portfolio returns based on firm size to illustrate the size effect across all valuation quartiles, 1999-2012 for a) $\mathrm{P} / \mathrm{B}, \mathrm{b}) \mathrm{P} / \mathrm{E}$, c) $\mathrm{P} / \mathrm{CF}$ and d) DY

The problem with the abovementioned results is that no statistical tests were conducted on them; the analysis is mostly comparative and observational. Moreover, standard deviations and risk-adjusted returns could have provided further information about the data in Table 6.

Comparing the two-factor portfolios with previous research on the JSE yields some supporting results. Van Rensburg and Robertson (2003), later affirmed by Strugnell et al. (2011), examined how $\mathrm{P} / \mathrm{E}$ and firm size interacted and found the value and size effects to be independent of each other. Furthermore, this result was also confirmed internationally by Bauman et al. (1998). Bauman et al. (1998) and Dhatt et al. (1999) found that small-cap value stocks outperformed small-cap growth stocks, which also occurred, on average, in this study. Expanding this result to all of the multiples, it appears that holding a small stock will generate excess returns regardless of the ratio, suggesting that size is independent of the valuation multiple. However, as in the case of $\mathrm{P} / \mathrm{E}, \mathrm{P} / \mathrm{CF}$, and $\mathrm{DY}$, the value premium complements the size premium somewhat.

\section{Conclusions and future work}

Portfolios were constructed using the 165 shares listed on the JSE Africa All Share Index based on four valuation criteria, as well as market capitalisation. These portfolios were used to detect a value effect and a small firm effect, respectively. The portfolios used for detecting the value premium generated mixed results. In the 14-year period from 1999 to 2012, value stocks outperformed growth stocks when the portfolios were based on $\mathrm{P} / \mathrm{E}$ and $\mathrm{P} / \mathrm{CF}$, despite being coupled with the highest volatility and moderate risk-adjusted returns. When the portfolios were based on $\mathrm{P} / \mathrm{B}$ and $\mathrm{DY}$, growth stocks outperformed value stocks and showed moderate volatility, as well as high riskadjusted returns. It was also noted that over the 14-year period, each portfolio outperformed the index.

With regards to the portfolios created based on market capitalisation, it was clear that a noteworthy size effect existed on the JSE. Small-caps did not outperform largecaps every year, but when they did, they outperformed by a large and significant margin. Of the size groups, the smallcaps displayed the highest geometric mean returns, high risk-adjusted returns, as well as the highest variability in returns over the whole period.

The value, growth and size premiums became more prominent in the two-factor models (where the valuation multiples were further sub-divided by firm size). Regardless of valuation multiple, the size premium was evident. In addition, the extent of the size premium was larger than either the growth or value premiums. It was also observed that both the size and value premiums acted independently of each other. However, small-cap value firms appeared to be the overall top performers, generating returns in excess of $32 \%$ in the period examined. Large-cap growth stocks outperformed large-cap value stocks by an average of $5,4 \%$ over the period. The mid-cap stocks showed that there was very little difference between the growth and value stock performance. 
As an investor, one cannot simply rely on superficial indicators, like valuation multiples or market capitalisation, as a basis for investment decisions. Regardless of which multiple was examined, neither value, growth, small-cap, nor large-cap always outperformed its respective other in every year. It is imperative for investors to conduct significant research into the stocks they plan to buy.

While some of the results presented here verify those found internationally, as well as domestically, other parts show trends that were not identified in those same studies. The research conducted goes so far as to identify whether value and size premiums exist on the JSE. It does not try to offer an explanation as to why the observed value, growth and size premiums occur.

Additional research could be conducted to explain whether the premiums identified in this study are independent, or are associated with market inefficiencies in a developing market; riskiness of stocks; illiquidity of small-cap stocks; investor overreactions; transaction costs; or for other reasons that have been overlooked.

Mean reverting qualities of small- and large-cap stocks, as well as value and growth stocks could also be tested. Winner and loser portfolios could be created that comprise best and worst performing stocks per year - for each stock type - and holding them for variable time periods. This would determine which stock types revert to their means; the time taken for mean reversion to occur, if at all; and whether the magnitude of the reversion varies based on stock type. Part of the empirical research would be to investigate the behaviour of market participants and how they react to different market conditions, such as the 2008 credit crisis. These findings could then be used to further explain investor behaviour, along with the effects that the credit crisis, and other booms and busts, may have had on stock returns and trends on the JSE.

Explaining why the various premiums exist on the JSE, why different price multiples benefit growth rather than value firms, whether mean reversion exists on the JSE, and the impact of the 2008 financial crisis provides sufficient grounds for future work to be conducted.

\section{References}

Arbel, A. \& Strebel, P. 1982. 'The neglected and small firm effects', The Financial Review, 17(4): 201-218.

Auret, C. \& Cline, R. 2011. 'Do the value, size and January effects exist on the JSE?', Investment Analysts Joumal, 74: 29-37.

Balvers, R., Wu Y. \& Gilliland, E. 2000. 'Mean reversion across national stock markets and parametric contrarian investment strategies', The Journal of Finance, 55(2): 745777.
Banz, R, 1980. 'The relationship between return and market value of common stocks', Journal of Financial Economics, $\operatorname{March}(9): 3-18$.

Barber, B.M. \& Lyon, J.D. 1997. 'Firm size, book-tō-market ratio, and security returns: A holdout sample of financial firms', The Journat of Finance, 52(2): 875-883.

Basu, S. 1977. "The investment performance of common stocks in relation to their price-earnings ratios: A yest of the efficient market hypothesis', The Journal of Finance, 32(3): 663-682.

Bauman, S.W., Conover, M.C. \& Miller, R.E. 1998. 'Growth versus value and large-cap versus small-cap stocks in international markets', Financial Analysts Journal, 54(2): 75-89.

Blount, G. 2010, Growth stocks don't grow. Mail and Guardian. [online] URL: http://mg.co.za/article/2010-07-12growth-stocks-dont-grow.

Brink, I. 2010. Small cap investing. Funds on Friday. [online] URL: http://www.stringfellow.co.za/publications/ FoF_26032010_GLC_Small_Caps.pdf.

Chan, K.C. \& Chen, N. 1991. 'Structural and return characteristics of small and large firms', The Journal of Finance, 46(4): 1467-1484.

Chan, L.K.C. \& Lakonishok, J, 2004. 'Value and growth investing: Review and update', Financial Analysts Journal, 60(1): 71-86.

Cochran, S.J. \& DeFina, R.H. 1994. 'International evidence on mean reversion in stock prices", Quarterly Journal of Business and Economics, 33(2): 79-87.

Cubbin, E., Eidne, M., Firer, C. \& Gilbert, E. 2006. 'Mean reversion on the JSE', Investment Analysts Journal, 72: 3142.

Damodaran, A. 2012. Investment philosophies. 2nd Edition. Hoboken, New Jersey: John Wiley \& Sons, Inc.

De Bondt, W.F.M. \& Thaler, R. 1985. 'Does the stock market overreact? ${ }^{*}$, The Journal of Finance, 40(3): 793-805.

De Bondt, W.F.M. \& Thaler, R.H. 1987. 'Further evidence on investor overreaction and stock market seasonality', The Journal of Finance, 42(3): 557-581.

Dhatt, M.S., Kim, Y.H. \& Mukherji, S. 1999. 'The value premium for small-capitalization stocks', Financial Analysts Journal, 55(5) 60-69.

Dimson, E., Nagel, S. \& Quigley, G. 2003. 'Capturing the value premium in the United Kingdom'. Financial Analysts Journal, 59(6): 35-45. 
Eun, C.S., Huang, W. \& Lai, S. 2008. 'International diversification with large- and small-cap stock', Journal of Financial and Quantitative Analysis, 43(2): 489-523.

Fama, E.F. \& French, K.R. 1988. 'Permanent and temporary components of stock prices, Journal of Political Economy, 96(2): 246-273.

Fama, E.F. \& French, K.R. 1992. 'The cross-section of expected stock returns', The Journal of Finance, 47(2): 427465 .

Fama, E.F. \& French, K.R. 1998. 'Value versus growth: The international evidence', The Journal of Finance, 53(6): 1975-1999.

Graham, M. \& Uliana, E. 2001. 'Evidence of a value-growth phenomenon on the Johannesburg stock exchange', Investment Analysts Journal, 53.

Hodnett, K., Hsieh, H. \& Van Rensburg, P. 2012. Payoffs to equity investment styles on the JSE securities exchange: The case of South African equity market', International Business \& Economic Research Joumal, 11(1): 19-31.

Horowitz, J.L., Loughran, T. \& Savin, N.E. 2000. 'Three analyses of the firm size premium', Journal of Empirical Finance, 17(4): 379-418.

Hsieh, H. \& Hodnett, K. 2011. 'Timing of mean reversals on the JSE securities exchange (JSE): The case of South Africa', Journal of Applied Finance and Banking, 1(1): 107130.

Jagadeesh, N. \& Titman, S. 1993. 'Returns to buying winners and selling losers: Implications for stock market efficiency, The Journal of Finance, 48(1): 65-91.

Jagadeesh, N. 1991. 'Seasonality in stock price mean reversion: Evidence from the U.S. and the U.K.", The Journal of Finance, 46(4): 1427-1444.

Keim, D.B. 1982. 'Size-related anomolies and stock return seasonality: Further empirical evidence', Journal of Financial Economics, 12(1): 13-32.

Kim, M.J., Nelson, C.R. \& Startz, R. 1991. 'Mean reversion in stock prices? A reappraisal of the empirical evidence", The Review of Economic Studies, 58(3): 515-528.

Lakonishok, J., Shleifer, A. \& Vishny, R. 1994. 'Contrarian investment, extrapolation, and risk', The Journal of Finance, 49(5): 1541-1578.

McQueen, G. 1992. 'Long-horizon mean-reverting stock prices revisited'. Joumal of Finance and Quantitative Analysis, 27(1): 1-18.

Muller, C. 1999. 'Investor overreaction on the Johannesburg stock exchange', Investment Analysts Journal, 49.
Page, M.J. \& Way, C.V. 1992. 'Stock market oyer-reaction: The South African evidence', Investment Analysts Journal, Summer: $35-49$.

Poterba, J.M. \& Summers, L.H. 1988. 'Mean reversion in stock prices: Evidence and implications', Journal of Financial Economics, 22(1): 27-33.

Reinganum, M.R. 1982. 'A direct test of roll's conjecture on the firm size effect', The Journal of Finance, 37(1): 27-35.

Roll, R. 1981. 'A possible explanation of the small firm effect', The Journal of Finance, XXXVI(4): 879-888.

Strugnell, D., Gilbert, E. \& Kruger, R. 2011. 'Beta, size and value effects on the JSE: 1994-2007', Investment Analysts Journat, 74: 1-17.

Van Rensburg, P. \& Robertson, M. 2003. 'Size, price-toearnings and beta on the JSE securities exchange', Investment Analysts Journal, 58: 7-16. 